\title{
Tax Policy and Firm Entry and Exit Dynamics: Evidence from OECD Countries
}

\author{
RICHARD KNELLER ${ }^{\dagger}$
}

DANNY MCGOWAN $\ddagger$

\begin{abstract}
In this paper we study the effects of reforms to corporate and personal income taxation on the rate of firm entry and exit using industry data for 19 OECD countries from 1998 to 2005. Using a difference-in-differences approach to correct for endogeneity bias we find that increases in corporate taxation affect entry but not exit. This drop in entry is statistically and economically significant, representing a reduction of $6.3 \%$ of pre-treatment levels. A number of placebo and falsification tests suggest that our inferences are not confounded by other factors. For example, the results are specific to the mediating variable used, and our identification strategy is sharpened by a triple-difference specification which rules out alternative fiscal explanations and an instrumental variables technique that leverages instruments found to influence tax policy by the political economy literature. The effects of personal taxation depend upon the marginal tax rate that is altered. Increases in marginal tax rates applied at low income levels negatively affect entry and positively affect exit, whereas marginal tax reforms at higher income levels have the opposite effect.
\end{abstract}

Keywords: corporate taxation; personal income taxation; firm entry; firm exit

JEL codes: D22, H2, H32, L26

*Acknowledgements: We are grateful for comments received from Steven Klepper, Nicolas SerranoVerlade, seminar participants at the University of Oxford, Universitié Paris 1 Panthéon-Sorbonne and the ESRC/HMRC International Conference on Taxation Analysis. The authors gratefully acknowledge financial support from the ESRC under project no. RES-194-23-0003.

† Authors' affiliations: University of Nottingham, School of Economics, University Park, Nottingham, NG7 2RD, United Kingdom. Email: richard.kneller@nottingham.ac.uk; tel: +44 (0)115 951 4734; fax: +44 (0)115 9514159 (corresponding author).

‡ Bangor University, Business School, Hen Goleg, College Road, Bangor, LL577 2DG, United Kingdom. Email: d.mcgowan@bangor.ac.uk. 


\section{Introduction}

Since 2003 the World Bank has published indicators of the monetary and time costs that are incurred from the government regulation of the creation and closure of firms in different countries. This, along with the empirical evidence linking these costs of regulation to the rate with which new enterprises enter and exit an industry (Scarpetta et al., 2002; Klapper et al. 2006), has led to increased pressure on policy makers to improve the conditions for entrepreneurship. ${ }^{1}$ Firm dynamics (entry and exit rates) are viewed as important because of their relationship with aggregate output and productivity growth (Foster et al., 2001; Baldwin and Gu, 2002; Disney, et al., 2003) and flows into and out of unemployment (Bartelsman et al., 2005). It has also been argued that they provide insights into the efficiency with which resources are allocated within the economy and are therefore a possible explanation of differences in per capita income levels across countries (Bartelsman et al. 2009).

In this paper we focus on the effects of a narrow aspect of the policy environment on firm entry and exit rates, the effects of tax policy, exploiting variation in the size and type of tax changes in a cross-country setting across time. ${ }^{2}$ As discussed by Da Rin et al. (2011), tax policy is a much more flexible policy instrument compared to many of the others that may affect entry and exit. ${ }^{3}$ By studying the effects of tax policy across countries we build closely on the work of Da Rin et al. (2011) and Djankov et al. (2010). Da Rin et al. (2011) use industry-level data for 17 European countries to examine whether corporate income taxation induces entry through the incorporation of new companies. They find a significant relationship that suggests higher corporate tax rates reduce the rate of incorporation, where this is robust to the use of instrumental variables to correct for any endogeneity bias. Djankov et al. (2010) take a somewhat different approach and use survey-based information to build the tax burden of a standardised domestic company in a cross-section of developed and developing countries. They also find that a higher corporate tax burden significantly reduces the rate of entry, but find no effect from the top personal income tax rate.

We extend the work of Djankov et al. (2010) and Da Rin et al. (2011) to study a set of complementary questions. Our primary interest is whether the effects on entry rates they uncover are also important for the rate of exit. Exit rates are of interest because they capture the response by existing enterprise owners to tax policy changes. Existing entrepreneurs, because of the investments they have made in their business, might be expected to respond to different tax changes compared

\footnotetext{
1 According to the World Bank (2008) 116 countries have made 193 different reforms since the publication of these data. 2 Bartelsman et al. (2009) provide some discussion of the advantages and disadvantages of the use of cross-country versus within-country data.

${ }^{3}$ According to the World Bank (2008) report there were 29 reforms to entry regulations amongst OECD countries between 2003 and 2008. For comparison, we have 211 different tax changes (across 4 measures of taxation) in an unbalanced panel of 17 European countries between 1998 and 2005 that make up our data.
} 
to those who aim to start a new enterprise. We aim from this to provide some insight into whether tax changes cause adjustment to the stock of enterprises by affecting entry rates, exit rates, or both. We are not aware of similar studies that have the effects of taxation on exit rates across countries and industries, although there does exist a literature that has studied exit decisions using US micro data. Within this literature Gurley-Calvez and Bruce (2008) find that increased income taxation reduces the duration of self-employment, whereas cfinds that higher relative marginal tax rates on self-employment income do not necessarily increase the probability of exit. ${ }^{4}$

A second contribution we make is to use a broader measure of entrepreneurship. In theoretical models of entrepreneurship, tax changes induce both the creation of new enterprises and switching between enterprise forms. For example, an increase in income taxation may induce some entrepreneurs to incorporate their enterprises in order to minimise their overall tax liability. Accurate forecasting of the effects of tax changes on enterprise behaviour requires information on the empirical importance of any substitution effects and therefore evidence using aggregated data of the type we use, as well as evidence using use a narrow range of enterprise types as in Djankov et al. (2010) and Da Rin (2011). For this task we use a new Eurostat-OECD data set that measures entry and exit rates by 'all enterprises', where this includes enterprise forms that include limited liability companies, partnerships and sole-proprietors, on a consistent basis across countries (and time). ${ }^{5}$ The diversity in enterprise types included in the data provides motivation for the study of the effects of corporate income tax reform alongside those of personal income taxation and therefore offers an interesting comparison to the results for the same types of taxation reported in Djankov et al. (2010).

To answer these questions our empirical design builds on evidence form the I-O literature on entry and exit rates and from the study on entry rates and entry regulation by Klapper et al. (2006) in particular. To address the possibility that there are hard to measure time-varying country-specific factors that are omitted from the regression we exploit the panel structure of the data to include a full set of country-time ${ }^{6}$ and industry fixed effects in a difference-in-differences type regression (Angrist and Pischke, 2009). These country-time effects attempt to capture omitted factors such as the attitude of the ruling government towards private enterprise, which are likely to affect tax policy as well as its treatment of the business environment and therefore entry and exit rates. As the

\footnotetext{
4 There is also a larger literature that studies the probability of being self-employed using micro data. In many countries the self-employed do not need to register as a firm in the business register and this may or may not generate differences between our results and those found using such a measure. Key references on taxation and self-employment include Gentry and Hubbard (2000), Carrol et al. (1998), Papke (1991) and Cullen and Gordon (2007).

5 This is an extension of the data set used by Bartelsman et al. (2005).

${ }^{6}$ Klapper et al. (2006) use data for just two years and so include just a county fixed effect. As we have a longer time series we allow for the possibility that these country factors vary across years.
} 
country-time effects we include are collinear with tax reforms, we follow the same methodology as Klapper et al. (2006) and exploit differences in the underlying characteristics of an industry, its attractiveness to entrepreneurs, to identify the effects of the variable of interest. Klapper et al. (2006) use entry costs as the relevant industry characteristic, which they approximate using the rate of entry into the same industry within the US, to study differences in the effects of the regulation of entry. In this paper, as it reflects the tax base for corporate taxation, we use profitability as the industry characteristic, ${ }^{7}$ where we also use US data to measure this. As discussed by Klapper et al. (2006), while this approach can tell us whether taxation operates in the expected manner, the disadvantage is that we cannot identify the overall magnitude of its effects on entry and exit rates. In addition to this, to account for the strong interdependence between entry and exit rates reported by Geroski (1995) and many others we estimate a system of equations, while we follow Burke et al. (2009) and Manjon-Antolin (2010) and control for any lagged adjustment. We show in the paper that the conclusions that are drawn about the effects of tax policy, and that the effects of taxation on exit rates in particular, are unreliable without controlling for its effects on entry. The inclusion of the lagged terms allow us to provide evidence on the persistence of entry and exit rates to tax changes.

Our empirical evidence suggests that firm dynamics are affected by changes to tax policy, but that their effect on entry rates differs compared to that for exit rates and according to the type of taxation. We find that existing entrepreneurs appear much less responsive to tax policy changes than those starting a new business. Entry rates are affected by adjustments to either personal and corporate income tax rates, whereas exit rates, which capture the response of those that are currently enterprise owners, are only weakly affected by adjustments to personal income taxes and not at all by corporate taxation. This evidence provides a motivation for future theoretical analysis of the causes of asymmetries in models of enterprise behaviour and we describe some possible mechanisms in the paper. These include differences in the risk-preferences of individuals in the standard risk-versus-return model of entrepreneurship (Gentry and Hubbard, 2000) or the presence of sunk costs to creating a new business (Hopenhayn, 1992).

Our evidence for corporate taxation on entry rates is in line with the evidence in Djankov et al. (2010) and Da Rin et al. (2011). Increases in corporate tax rates are found to decrease entry rates, where in our framework those effects are strongest in more profitable industries. The effects on exit rates are new, but differ from those found using micro data on self-employment by Gurley-Calvez and Bruce (2008). The type of data on exit we use is an obvious explanation for this difference and therefore indicate that tax-induced substitution in enterprise form might be empirically important.

7 We fix this industry characteristic to be constant across time (and countries) such that it plays no additional role in identifying the effects of tax changes. 
We also show however that the results for exit rates we derive are dependent on controlling for the (positive) correlation between entry and exit rates (Geroski, 1995). In regressions for the rate of exit where we do not control for entry rates we find the unexpected outcome that higher corporate taxation decreases the rate of exit. We conclude from this that increases in corporate taxation does affect the rate of exit, but only though its effects on the rate of entry.

The effects of personal income tax reforms are more complicated than those for corporate taxation, varying according to which marginal tax rate is altered. Here our results suggest that an increase in the marginal rate of personal income taxation at low-income levels $(67 \%$ of the average wage) lowers entry rates, whereas and increase to marginal tax rates applied at high income levels raises entry rates and lowers exit rates. These findings on entry are in-line with the time-series evidence for self-employment in the US by Blau (1987) and Bruce and Mohsin (2006). We are not aware of any similar evidence on exit rates. In all cases we find that there is little persistence in the effects of tax policy. Almost all of the effect has disappeared from the data within a couple of years.

Are these effects causal? For that to be the case the difference-in-differences approach we use requires very specific some assumptions to hold. We test the robustness of our results to a number of possible alternative explanations, including whether profitability is the relevant industry characteristic, using falsification tests of the timing of tax policy changes, and by controlling for a broad range of other non-tax policy changes and for political variables. Our identification strategy is sharpened by the use of an instrumental variables technique which leverages factors found to influence tax policy in the political economy literature. We show that our results are robust to all of these additional tests and conclude that the effects on entry and exit we capture are specific to the tax policy changes that we observe in the data, suggesting that they might be causally related.

The rest of the paper is organised as follows. In section 2 we discuss the existing theoretical and empirical evidence of the relationship between tax policy and the decision to become an entrepreneur. Section 3 details the empirical methodology we adopt in the paper, while Section 4 describes the data sources and the variation in entry and exit rates and tax rates that exist in our data set. Section 5 reports and interprets the results from our empirical strategy. In this section we report and discuss our baseline estimates for corporate taxation, a series of robustness tests and for personal income taxation. Section 6 draws some conclusions from the study.

\section{Existing Evidence}

The positive effect that firm dynamics (entry and exit) make to a broad range of economic outcomes, including innovation (Aghion and Howitt, 1992; Romer, 1990), productivity growth (Bartelsman and Doms, 2000; Foster et al., 1998; Disney et al., 2003) and employment (Barnes and 
Haskel, 2002; Bartelsman et al., 2005) has led to growing interest in the policy determinants of entry and exit. Perhaps best known are the studies by Klapper et al. (2006) and Scarpetta et al. (2002). Klapper et al. (2006) use data on the creation of European firms to study the effects of entry regulation. These regulations include the monetary and time costs of dealing with the necessary bureaucracy to register a new business. Using the US as a proxy for the 'natural rate' of entry they find that regulations hamper entry, especially in industries that have low entry barriers. ${ }^{8}$ Scarpetta et al. (2002) take a broader set of policy variables and study the effects of product and labour market regulations on entry rates using OECD data. Their measure of product market regulation includes the legal and administrative barriers to new firm creation studied by Klapper et al. (2006), but also the regulation of international trade and investment and intervention in markets directly by states. They also use a measure of employment protection legislation and find a significant effect from this type of regulation on entry rates.

In this paper we are interested in the effects of taxation on firm entry and exit rates. As discussed already the papers that are closest to ours are those by Da Rin et al. (2011) and Djankov et al. (2010). These studies focus on whether corporate taxation discourages entrepreneurship. Da Rin et al. (2011), for example, examine whether corporate income taxation induces entry through the incorporation of new companies. Using industry-level data on the rate of entry by incorporation in 17 European countries from 1997 to 2004 they uncover a significant non-linear relationship that is robust to the use of instrumental variables to correct for any endogeneity bias. In their preferred specification they find that a reduction of the corporate tax rate from the median $(30.04 \%)$ to the first quartile $(27.57 \%)$ implies a 0.88 percentage point increase in the entry rate, whereas for the same sized reduction from the third quartile $(33.44 \%)$ to the median, entry increases by 0.27 percentage points. The approach taken by Djankov et al. (2010) uses survey-based information to build the tax burden of a 'standard' company with similar characteristics across all countries (the company produces and sells flower pots). They find that this measure of the tax burden is significantly negatively correlated with the rate of entry in a cross-section of developed and developing countries, as well as other performance measures such as aggregate investment and FDI. For a measure of the top personal income tax rate they can find no significant relationship with rates of entrepreneurship however.

There also exists a relationship between the questions of interest in this paper and a much larger literature on taxation and entrepreneurship. Most of the theoretical models on this topic typically assume that the decision to create a firm by an entrepreneur is a discrete choice and affected by tax rates as potential entrepreneurs compare the after-tax returns to employment versus

\footnotetext{
${ }^{8}$ Discussion of related evidence can be found in Djankov (2009).
} 
entrepreneurship (Gentry and Hubbard, 2000). The effects of tax policy on the decision to move into entrepreneurship are therefore assumed to be symmetric to the decision for existing entrepreneurs to close their businesses. Entrepreneurship income is usually modelled as involving greater variability than employment income, such that it is a trade-off between risk and return. ${ }^{9}$ The returns to entrepreneurship will be affected by the different tax variables, according to whether the entrepreneurs' income is subject to personal income taxation or corporate taxation, the tax rate on employment income and the entrepreneur's attitude towards risk (Kihlstrom and Laffont, 1979). In general, higher corporate taxation in these models is associated with lower returns to entrepreneurship, making employment relatively more attractive. For personal income taxation the relationship with the total stock of enterprises is complicated further by the combination of the uncertainty of income as an entrepreneur and the greater complexity of the tax schedule usually assumed for personal income taxation. The effects of income tax changes now depend on which specific marginal tax rate (at which level of income) is altered, as well as the value of any tax thresholds, and the returns to employment relative to the good and bad states of entrepreneurship.

The empirical predictions from these models have mostly been tested using data on entry into self-employment. Some of these have used time series data for one or a number of countries, for example Blau (1987) and Robson and Wren (1999), whereas others have been based on micro data, for example Long (1982), Gordon (1998), Bruce and Mohsin (2006), Cullen and Gordon (2007) and Stabile (2004). In terms of the type of tax measures used we are closest in our work to that using time series data. Blau (1987) finds that higher marginal tax rates in the upper income brackets of the personal income tax system have a positive effect on the decision to be self-employed and that the opposite is true in lower income brackets using aggregate U.S. time-series data to examine the changes in self-employment between 1948 and 1982.10 Here, as tax rates become more progressive self-employment becomes less, not more, popular.

Bruce (2002) and Gurley-Calvez and Bruce (2008) are rare examples of studies that consider the effects of taxation on the decision to close a firm, or specifically the duration of entrepreneurial activity (measured as self-employment). Gurley-Calvez and Bruce (2008) find that greater entrepreneurial taxes shorten spells of entrepreneurial activity, whereas an increase in wage taxation lengthens them.11 Bruce (2002) however finds that higher relative marginal tax rates on self-employment income do not necessarily increase the probability of exit.

\footnotetext{
9 There is considerable empirical evidence to support this claim (see for example Holtz-Eatkin et al., 2000).

10 Bruce and Mohsin (2006) also find that the top rate of personal income taxation is positively correlated with the selfemployment rate in the United States. The coefficient estimate is, however, small and personal income tax rates are not found to be cointegrated with self-employment rates.

11 Taylor (1999) also studies exit from self-employment using time-series data but does not include taxation in the model.
} 


\section{Econometric Strategy}

The empirical strategy we adopt in this paper differs from that used in many of the above papers, in part because of the difference in the type of data used, but also because it draws more closely from the IO literature on entry and exit dynamics. We model entry and exit using the pair of regressions set out as equations (1) and (2) below. The (log) rate of entry (EN) or exit (EX) in industry $j$ of country $i$ at time $t$ is modelled as a function of both lagged (logged) entry and exit. The equations are therefore consistent with a jointly determined long-run equilibrium between entry and exit rates, although given the relatively short time series element to the panel data available to us we caution against making such a statement too strongly. For that reason, whilst we use the label 'longrun effects', in the table we describe these as persistent effects in the text. By including the lagged dependent variable in the regression we follow Burke et al. (2009) and Manjon-Antolin (2010) who find such dynamic adjustment parameters to be important in a model of entry/exit rates, while the inclusion of the cross-equation terms attempts to control for the cross-equation correlation between the error terms of the regressions (Geroski, 1995; Baldwin and Gu, 2002). We estimate equations (1) and (2) using a feasible generalised least squares estimator which uses a weighting matrix to provide more efficient estimates. ${ }^{12}$ The effects of tax reforms are denoted by $\Delta T$ in equations (1) and (2) and vary across countries (i) and time $(t) .{ }^{13}$ We also control in the regression for changes in industry-level demand (logged) through the MA variable, the construction of which we describe below, while $\varepsilon_{i j t}$ is a random error term. ${ }^{14}$

$$
\begin{aligned}
& \Delta E N_{i j t}=\alpha+\alpha_{1} E N_{i j t-1}+\alpha_{2} E X_{i j t-1}+\alpha_{3} \Delta E X_{i j t-1}+\alpha_{4} M A_{i j t-1}+\alpha_{5} \Delta M A_{i j t-1}+\alpha_{6} \text { Indust }_{j} * \Delta T_{i t}+\gamma_{i t}+\gamma_{j}+\varepsilon_{i j t} \\
& \Delta E X_{i j t}=\beta_{0}+\beta_{1} E X_{i j t-1}+\beta_{2} E N_{i j t-1}+\beta_{3} \Delta E N_{i j t-1}+\beta_{4} M A_{i j t-1}+\beta_{5} \Delta M A_{i j t-1}+\beta_{6} \text { Indust }_{j} * \Delta T_{i t}+\varphi_{i t}+\varphi_{j}+\varepsilon_{i j t}
\end{aligned}
$$

\subsection{Omitted Variable Bias and Identification}

An important concern when trying to identify the effects of tax changes on firm dynamics is that we may simply capture the effect of a range of other difficult to measure time-varying policy variables that are correlated with the tax reforms of interest. The error term in our regressions may

\footnotetext{
12 The correlation between the error terms in regressions 1 and 2 of Table 7 is calculated to be -0.1933 . A Breusch-Pagan test of independence gives $\mathrm{chi}^{2}(1)=72.637(\mathrm{p}$-value $=0.000)$, indicating a statistically significant correlation between the errors in the two equations.

13 The regressions do not contain a long-run effect of taxation. We do not rule out the possibility that taxation may have a persistent effect on entry and exit, rather that it is not heterogeneous across industries. Several robustness checks failed to find any evidence of persistent effects of taxation on entry or exit rates.

14 We use a log-linear form to reflect the fact that entry and exit rates are bounded at zero.
} 
represent unobservable (to the econometrician) policy detail or political related barriers to entrepreneurship that may be correlated with the decision to increase or reduce a particular form of taxation. These factors may include for example, the ruling party's policy towards entrepreneurship, as embodied in the rules and regulations governing business start-up and closure described in the World Bank Doing Business reports. Where tax rate changes are correlated with say the decision to alter the number of procedures and regulatory hurdles which must be passed to create a firm, the tax reforms of interest will be correlated with the error term, such that the variable is endogenous and OLS therefore yields biased and inconsistent coefficient estimates.

If, as seems likely, a governments' decision to change tax rates is related to the level of entry and exit that takes place in a country across industries (in part because entrepreneurship is hard to precisely define and to measure, OECD 2009) these omitted determinants of tax policy are likely to be country specific and to vary across time. We therefore control for the omission of relevant country-year factors by including a full set of country-time fixed effects. In addition to the aforementioned policy factors, the country-time effects will further capture any other time-varying country-level influences on firm entry and exit, including the direct effects of taxation. A similar approach to this problem can be found in Klapper et al. (2006).

As the country-time effects that we include are perfectly collinear with the (country-time) tax reforms that are of interest to identify the effects of taxation we follow advice from Angrist and Pischke (2009) and evidence from Klapper et al. (2006) and exploit the cross-industry differences in the effects of taxation in a difference-in-differences estimation framework. The identifying assumption that we make is that there are inherent characteristics of an industry that ensure that their response to a change in taxation differs. We choose as the industry variable a measure of profitability as it is the tax base for corporate taxation and has been found to attract entrepreneurs (Kessides, 1991; Schwalbach, 1991) and cause exit (Sleuwaegen and Dehandschutte, 1991).15 Moreover, this assumption is in line with theoretical models of the relationship between taxation and entrepreneurial entry where entry decisions are based upon the returns to entrepreneurship (Gentry and Hubbard, 2000). We anticipate that an entrepreneur's decision to enter or exit profitable sectors is more sensitive to the same change in taxation compared to less profitable sectors, because the impact on the expected returns to entrepreneurship is greater.

The profitability of an industry in a given country is potentially endogenous of course, its values determined in part by the number of firms in that industry and therefore by the rate of entry and exit that takes place. To control for this problem we follow Klapper et al. (2006), Rajan and Zingales

${ }^{15}$ It is worth noting that the correlation between profitability and entry is positive and negative for exit. Therefore any negative effects that we find from tax policy changes on entry and the positive effect on exit are not explained by the (time invariant) industry profitability variable. 
(1998), Nunn (2007), Manova et al. (2011) and others in using data for the US and impose common values for an industry across countries. We choose the US because it is not included within our data set and it is likely to represent markets that are most free of the distortions from taxation or other government regulation (Klapper et al., 2006). We use time-invariant US data on profitability in each 2-digit industry and apply this across all countries and years in our data set. The assumption we make is that whilst the variation in profitability across countries and time is endogenous, the differences between sectors is not and is therefore suitable for identifying the effects of taxation. Or as Klapper et al. (2006) write "all that is important for us is that the rank ordering of entry in the United States correspond to the rank ordering of natural barriers across industries, and that this rank ordering carry over to other countries" (p605). It is also important to state that the industry profitability variable plays no other role in the regression other than helping to identify the effects of tax changes. The disadvantage of this methodology is that we cannot derive the overall magnitude of the effects of taxation, only the relative magnitude on more profitable industries (Klapper et al., 2006). We consider the robustness of our findings to a range of other possible explanations in Section 5.2.

The effects of changes in taxation on entry/exit are captured by the interaction between the time invariant industry variable and $\Delta T$ in the regression equation. We also include in the regression a set of industry fixed effects, intended to capture differences in the sunk costs of entry or exit between industries, profitability etc, and a measure of market demand or market access (labelled MA in the regression). The measure of market access (MA) that we use is based on Harris (1954) and includes the domestic market and a weighted average of foreign markets, where the distance between countries determines the weights that are used. We anticipate that industries-countries with large markets, or markets that are growing quickly, will have more entry and less exit.

\section{Data Description and Summary}

As discussed by Bartelsman et al. (2009), when conducting cross-country studies of firm dynamics it is important to make every attempt to harmonise the measures by imposing the same data requirements and aggregation methods of the underlying micro data. ${ }^{16}$ In this paper we use data on entry and exit drawn from the OECD-Eurostat Structural Demography Business Statistics (SDBS) data set that takes seriously the points raised by Bartelsman et al. (2009). This data source provides detailed information on the number and size of firms across (OECD) countries, industries (ISIC 2digit) and time as well as the number of new firms that enter or exit as a ratio to the remaining

16 Of interest, Bartelsman et al. (2009) also propose the use of a difference-in-differences approach to reduce the effects of any measurement error caused by differences in the collection and measurement of micro data across countries. 
population of firms. We use the 'all enterprises' variable in that database to measure entry and exit. An enterprise is defined in the data as "the smallest combination of legal units that is an organisational unit producing goods or services, which benefits from a certain degree of autonomy in decision-making, especially for the allocation of its current resources. An enterprise carries out one or more activities at one or more locations" (Eurostat-OECD, 2007). The legal forms included cover limited liability companies, partnerships, sole-proprietors and public corporations. We use data from manufacturing industries (ISIC codes 15-37) and from the service sector (ISIC codes 5074). As in Klapper et al. (2006), we therefore exclude observations from the agricultural, forestry and mining sectors as well as service sectors such as education and health services where public provision and public subsidy is more likely.

A birth of a new firm (or the closure of an existing firm) in this data set is defined as the creation (death) of an enterprise that is registered in the business register of that country corrected for errors. A birth amounts to the creation of a combination of production factors "with the restriction that no other enterprises are involved in the event. Births do not include entries into the population due to: mergers, break-ups, split-off or restructuring of a set of enterprises. It does not include entries into a sub-population resulting only from a change of activity" (Eurostat-OECD, 2007). ${ }^{17}$ Exits are defined in a similar way. Specifically, an exit is defined as closure (death); it does not capture exit through merger or absorptions nor is it due to firms switching into other industries. When combined, our data set covers 19 countries across both manufacturing and service industries (only 15 countries provide data on the services sector). The time periods available differ across countries (Table 1). For example, data for Belgium exists for 2 years. In comparison the time series for the UK, Sweden and Spain extend from 1998 to 2005.

\section{[Insert Table 1]}

To estimate the impact of corporate taxes and income taxes on entry and exit rates requires data on industry-level profitability and country-time specific statutory income tax rates. The use of data on statutory tax rates has the disadvantage that they may differ from the actual tax rates faced by individual entrepreneurs once allowances for losses, capital expenditure, expenses etc. have been deducted, but as noted by Djankov et al. (2010), they have the advantage of (extreme) simplicity and might plausibly be the tax rates that entrepreneurs look at when making their entry/exit decisions. The data for statutory corporate tax rates we use are obtained from EUROSTAT, Taxation Trends in the EU. We use two sources of data on personal income taxation across countries and time. Our first measure is the top statutory income tax rate used by Djankov et al. (2010), which we again obtain from the EUROSTAT Taxation Trends in the EU database. The advantage of using the top marginal

${ }^{17}$ For further information on these data see http://www.oecd.org/dataoecd/8/9/39974480.pdf. 
income tax rate is that it covers a relatively large number of countries and time-periods. Its disadvantage is that it is unlikely to fully reflect the complexity of the income tax system applied in most countries and which has been shown to be important in the theoretical models on this issue. It also lacks comparability across countries: data from the OECD shows that in 2004 the top tax threshold began at the mean of average wages in Denmark, at a multiple of 1.7 of average wages in the UK, 3.4 in France and 4.0 in Switzerland.

To try to capture this complexity, our second measure of personal income taxation is drawn from the OECD Tax database and measures the marginal tax rate for an individual with a wage income at $67 \%, 100 \%$ and $167 \%$ of the average wage in each country. ${ }^{18}$ The average wage is based on the average annual gross wage earnings of adult, full-time manual and non-manual workers in the industry (ISIC C to K). The results take into account basic/standard income tax allowances and tax credits and include family cash transfers. The disadvantage of this data source is that it is available for only 13 countries from 2001 onwards.

Information on the profitability of industries is calculated from the 2002 U.S. Benchmark InputOutput Data Table (U.S. Bureau of Economic Analysis, 2002). For each industry at the 2-digit ISIC level a profitability ratio is calculated from data on gross operating surplus divided by value added; this is applied to the whole period of our analysis, 1998-2005. To measure the effects of changes in domestic and foreign markets we follow Harris (1954) and calculate a measure of total market size as the sum of domestic and foreign income divided by the distance to that market. As in Hanson (2005) we allow the discount rate on distance to differ across industries. Market access (MA) is given by the following equation

$$
M A_{i j t}=\sum_{k=1}^{N} A C_{j k t} \text { Dist }_{i k}{ }^{-\delta j}
$$

where AC denotes apparent consumption (the sum of output - exports + imports); $i$ denotes the home country, $k$ foreign countries, $t$ represents time and $j$ industries; Dist ${ }_{i k}$ refers to the distance between the home and the foreign country and $\delta_{j}$ is the discount parameter on distance in industry $j$. When we set $\delta_{j}=-1$ this collapses to the specification used by Harris (1954). In the absence of information on exports and imports for the service sector in those industries apparent consumption (AC) is measured using output data only. AC is calculated using deflated series taken from the EU Klems and OECD STAN databases. We set the value of distance equal to those reported in Table 3

18 The marginal income tax rates are the 'all-in' variables in that data set. 
for manufacturing by Kneller et al. (2008). For services we take the value estimated by Head et al. (2009) of -1.35 .19 We log the MA variable for inclusion in the regression.

\subsection{Summary Statistics}

The data on entry and exit rates available from OECD-Eurostat display similar properties to those reported in other studies. In the cross-section these include 1) there is large variation in entry and exit rates across industries 2) there is a strong positive correlation between entry and exit rates and 3) some industries, most noticeably in services, and some countries have higher rates of both entry and exit. To summarise the patterns of entrepreneurship within our data we present the average rate of entry and exit for each country and broad industry (manufacturing or services) in Table 2. The evidence in this table confirms that the cross-country differences in the rate of firm turnover are indeed large. In the manufacturing data the country averages for entry lie in the range $4.38 \%$ per annum (Slovenia) to $10.58 \%$ (Latvia) and in the service data from $6.77 \%$ per annum (Sweden) to $13.36 \%$ per annum (Norway). The exit rates are in a similar range. These figures are also of a comparable magnitude to those reported in other studies. Bartelsman et al. (2005) for example report rates of churn (entry + exit) for 16 countries from the early 1980's to 2001 as between 20-25\% per annum. Similarly, Roberts and Tybout (1997) using data for Chile, Colombia and Morocco report turnover rates of between 25\% and 30\%, while Aw et al. (1997) report for Taiwan an exit rate of $87 \%$ over a 10 year period. Similar evidence can also be found in Bartelsman et al. (2009). The table also suggests a positive correlation between entry and exit rates. The correlation in entryexit rates when we use the 2-digit industry data used in our regressions is 0.88 . Higher entry is associated with higher exit. This correlation occurs because most of the firms that exit are recent entrants.

Table 2 suggests there are consistent differences in rates of entrepreneurship across industries. In all of the countries for which there are data on both the manufacturing and services sector, the rate of entry and exit in the service sector are higher than those for manufacturing. This presumably reflects differences in the fixed costs of market entry in these two sectors. The table also suggests that country-specific factors may also play a role in determining rates of entrepreneurship. The rate of entry and exit is consistently higher in both the manufacturing and services sector for the UK, compared to France, the Netherlands and Belgium for example.

\footnotetext{
19 We have considered the robustness of our findings to the assumptions regarding the importance of foreign markets. We calculated alternative measures of market size where we set the distance parameter equal to -1 for both manufacturing and services and a measure in which we attempt to reflect the difficultly in traded retail and wholesale trade and hotels and restaurants across borders. For this measure we set the distance parameter for those industries equal to -2 . In these industries foreign markets are relatively unimportant. Our results both for this and the tax variables are unchanged by these alternative estimates of market size.
} 
[Insert Table 2]

Cross-sectional differences in the rate of entry or exit will be captured in the regression by the inclusion of a full set of country-time and industry dummies. The effects of taxation are therefore identified using the within country-industry time variation in the data. We display evidence on this in Figures 1 and 2. These figures display the rate of entry and exit for the textiles and hotels and restaurant sectors in the UK, chosen as a country with one of the longest time series. The crosssectional stylised facts discussed above are again evident in these figures, while they also show there is a general stability in entry and exit rates over time. The evidence from these figures suggests that the within-industry variation in entry and exit rates is small relative to the variation between industries. The within industry-country variation in the rate of entry is $3.06 \%$ and $1.75 \%$ for exit, much smaller than the overall average for entry and exit at $8.9 \%$ and $7.3 \%$ respectively.

\section{[Insert Figure 1]}

[Insert Figure 2]

There is also significant variation in our tax variables across countries and time. Tables 3,4 and 5 display our data on income tax reforms (corporate and personal) that coincide with the sample window on entry and exit data for each country (see Table 1). In the table we display both the year of the reform and the size of the change in the tax rate. As they cover a longer time period we initially compare the corporate and the top income tax rate.

[Insert Table 3]

[Insert Table 4]

[Insert Table 5]

There are clear differences between the two types of tax reforms. For corporate income taxation we have evidence of 41 different tax reforms across 15 of the 19 countries that make up our sample. The majority of the tax changes observed during the sample window are negative, although there are three periods (one in Finland and two in Germany) where corporate tax rates increased. The largest tax change was in Italy in 1998, where corporate tax rates decreased by 11.9 percentage points. Four of the 16 countries have only one tax reform during the sample window, whereas at the other extreme there are six tax reforms in Germany and five in France. We have a larger number of reforms of the top personal income tax rate during the sample window; there are 49 tax reforms. Again interacting this with the profitability variable gives us a total of 1,372 possible tax episodes but as before this number falls as a result of missing data on entry and once we allow for dynamics in the regression.

There are a number of other noticeable differences between the two tax series. Compared to corporate taxation, changes in income taxation are clustered in a smaller number of countries; 14 
countries have tax reforms and 5 have no reforms. As a consequence there are just 16 time periods in which both personal and corporate taxation were altered in the same country. There are 4 countries for which we have a reform to corporate taxation but no personal income tax changes take place during the sample window (Latvia, Lithuania, Portugal and the UK) and 1 country for which the reverse occurs (Norway). Slovenia is the only country for which there are no types of tax reform. The top rate of personal income taxation is altered very frequently in some countries. For example there are three or more tax reforms in Belgium, Finland, France, Germany, Italy, Luxembourg, Norway and Sweden.

In Table 5 we compare the change in the marginal tax rate applied at income levels expressed as a percentage of the average wage. In this table we find there are 13 (out of 16) countries that have a tax reform in at least one country. This compares to 14 countries in Table 4 despite the smaller sample, where in Table 5 we find tax reforms in Portugal that were not in Table 4 . In total there are between 34 (marginal tax rate at 167\% of average wages) and 44 (marginal tax rate at $100 \%$ of average wages) tax reforms across the period that coincide with our entry and exit data. There are also differences between Tables 4 and 5 in the date at which tax reforms occur. Perhaps most obviously this occurs for Sweden, where in Table 4 we report that the top income tax rate was altered every year between 1998 and 2005 and Table 5 where we find that the marginal tax rate for an individual with an income equal to $167 \%$ of the average wage did not change. Data from the OECD suggests that the top tax threshold occurs at 1.8 times the average wage in Sweden in every year between 2000 and 2004, which may explain this difference

In Table 6 we present the correlation matrix for the changes in the five different tax variables we use in the paper. The correlations are uniformly low, they are never greater than 0.36 . These correlations do not increase markedly even when we use the tax rates rather than their changes. For example the correlation between the level of corporate taxation and the top personal income tax rate is 0.36 . Overall these low correlations suggest that the various tax variables are liable to capture different aspects of the variation in entry and exit rates across countries and time.

[Insert Table 6]

\section{Econometric Evidence}

\subsection{Corporate Taxation}

Given their availability for a longer time series and to aid comparisons with Da Rin et al. (2010, 2011) and Djankov et al. (2010) we begin with a discussion of the relationship between corporate tax rates and entry and exit. The results for the change in corporate taxation are presented in regressions 1 (entry rate) and 2 (exit rate) of Table 7. 
Before moving on to discuss the results for taxation we briefly discuss the results for the other control variables included in the regression equation. In regressions 1 and 2 the coefficients on the lagged dependent variables are negative and less than one. That they are both less than one in absolute terms implies that entry and exit rates are stable over time. Consistent with the evidence in Figures 1 and 2, entry and exit rates do not continue to explode upwards or downwards following a change to one of the variables in the equation. The signs on the lagged entry and exit variables in columns 1 and 2 indicate that changes in the independent variables, for example market size, alter the timing of entry and exit. An increase in market access for example will encourage the entry of new firms this period, but the next period entry rates will fall below normal levels. The consequence of this is that following a change in one of the determinants of entrepreneurship, entry and exit rates will ratchet up and down in a saw tooth motion back to the long-run rate. This pattern might occur because new entrepreneurs are able to affect the timing of entry and exit to a limited extent, across a couple of years or so, or because those providing finance to new entrepreneurs wish to diversify risk away from industries that have witnessed lots of entry and exit in a single period. That the cross-equation terms are also significant implies that any variable that causes entry rates to rise over time will also cause exit rates to increase the next time period, even if that variable itself has no direct effect on exit rates. Consistent with this view, the Eurostat FEED data confirm that many new firms quickly exit again: in the average OECD country 10 per cent of a new cohort of firms die within one year, while only around 80 per cent of the initial cohort survives for 2 years, 72 per cent after three and so on until on average 57 per cent remain after 5 years.

We also find evidence in Table 7 that market access matters for the rate of entry and exit. Regressions 1 and 2 show that increased market access does not have a statistically significant persistent effect on the rate of entry or exit but does impact on entrepreneurship over shorter time horizons. This supports evidence from Scarpetta et al. (2002) that the change in industry value added is positively correlated with rates of entry amongst 5 OECD countries. Regressions 1 and 2 also suggest the initial response of entry and exit to changes in market access are in different directions. In the entry regression (regression 1) the coefficient measuring the short-run effect of market access is large and positive, whereas in the exit regression (regression 2) the coefficient for this same variable is again large in absolute value, but now negative. This is an indication that in growing markets incumbents are able to capture additional market share which helps insulate against exit, while growing markets also attract more entrants. It follows from these patterns for entry and exit that larger markets tend to support a larger number of firms than smaller markets.

[Insert Table 7] 
For taxation we find that a change in the statutory corporate tax rate significantly affects the rate of entry (regression 1) in the expected manner. Higher corporate tax rates reduce the rate of entry that occurs, where the magnitude of this response increases with the profitability of the sector. As a reminder this effect on entry is net of any switching between incorporation and non-incorporation by entrepreneurs. Despite this, our evidence is consistent with the presence of either non-linearities in the effects of corporate taxation on entrepreneurship (Cullen and Gordon, 2007) or the strategic motives present in Appelbaum and Katz (1996). It also matches the evidence from Da Rin et al. (2011) and Djankov et al. (2010), albeit for a different measure of corporate income taxation. ${ }^{20}$

We use Figure 3 to provide some assessment as to the size of the effect of a decrease in corporate taxation on the rate of entry across industries. ${ }^{21}$ The average change in corporate taxation in our sample is -2.4 percentage points. We display the effect of a tax decrease of this magnitude for entry in an industry with a value of profitability equal to the $10^{\text {th }}, 25^{\text {th }}, 50^{\text {th }}, 75^{\text {th }}$ and $90^{\text {th }}$ percentiles of the profitability distribution. As Figure 3 makes clear, the effect of changes to corporate tax rates on entry rates differ noticeably across industries. We estimate that in the most profitable industries, defined by that at the $90^{\text {th }}\left(7^{\text {th }}\right)$ percentile of the profitability distribution, the percentage point increase in entry is around $0.87(0.74)$ percentage points in the first year, compared to 0.58 for an industry with a median level of profitability and $0.40(0.47)$ for an industry with a profitability at the $10^{\text {th }}\left(25^{\text {th }}\right)$ percentile. These effects quickly die away such that by year 3 the change in entry rates is less than 0.15 percentage points.

\section{[Insert Figure 3]}

Are these effects economically significant? From the perspective of the average annual change in entry rates within an industry the answer is yes. The annual change is on average 0.4 percentage points (with a standard deviation of 2.8). At the mean level of profitability the effect of a change in taxation is therefore about 20 per cent of the standard deviation of the change in entry rates. ${ }^{22}$ Despite differences in the measure of entrepreneurship and empirical methodology that we use in this paper, the size of these estimates of the change in entry rates stimulated by tax changes are also in line with those reported in Djankov et al. (2010) and Da Rin et al. (2011). According to Djankov et al. a 10 percentage point decrease in corporate taxation leads to a 1.4 percentage point increase in

\footnotetext{
${ }^{20}$ In contrast to Da Rin et al. (2011), we do not find a non-linear relationship between corporation tax and entry. In unreported regressions, available upon request, the square of the corporate tax variable enters insignificantly in both the entry and exit regressions. It would appear that non-linearities are only present in the relationship between the decision to incorporate a firm and corporate tax rates rather than between corporate taxation and the stock of firms.

21 The coefficients on the tax variables in a log-linear model indicate the percentage change in entry(exit) rates following a one unit change in taxation*profitability. In the construction of Figure 3 we convert these to a percentage point change in entry/exit rates from the long-run average across countries-industries-time in our data set of 8.9 per cent.

22 The inclusion of country-time dummies means we are unable to comment on the extent to which differences in tax policy explain differences in the rate of entry or exit between countries.
} 
the entry rate. In Da Rin et al. (2011) the relationship is non-linear, but is of the same order of magnitude. A reduction in the corporate tax rate from the median to the first quartile (about 2.5 percentage points) leads to an increase in entry rates of 0.88 percentage points, whereas a reduction from the third-quartile to the median (about 3.4 percentage points) implies an increase in the entry rate of 0.27 percentage points.

In contrast to the results for entry, in regression 2 we find no effect from corporate tax changes on the rate of exit. This is an interesting finding as it suggests that the effects of taxation on the total stock of enterprises occur largely by discouraging new entrants rather than encouraging existing entrepreneurs to close their business. Why then might owners of existing enterprises respond differently to a tax change compared to those individuals wanting to open a enterprise? A number of mechanisms could generate differences of this type. Even in the standard model of entrepreneurship (Gentry and Hubbard, 2000) if individuals have different preferences for risk aversion, as suggested by Kihlstrom and Laffont (1979) and Caliendo et al. (2009), and those that have low risk-aversion select into entrepreneurship for example, then the response to the same tax change can be expected to differ. Alternatively, if there are sunk costs to creating a new business (Hopenhayn, 1992), then this may cause hysteresis in the effects of tax policy changes of the type modelled for exchange rate shocks and the decision to export or not by Capma (2004). They might also be explained by the application of corporate tax policy in OECD countries and the size of exiting firms however. The majority of the firms that die are (small, young and) loss-making and therefore do not incur corporate taxation. We leave the issue of which of these explanations dominates as an area for potential future research.

One possible explanation for the difference between our results for exit and those in Bruce (2002) and Gurley-Calvez and Bruce (2008) could stem from the type of data used. Those papers use information on self-employment to study entrepreneurial duration. It is therefore likely that where data on a single enterprise form includes the effects of any switching made by existing entrepreneurs to minimise their taxable income, such effects are netted out in our data and we capture just those that close their business and move into employment (or unemployment). That we find different effects from taxation might be used as evidence to suggest that the substitution between enterprise forms is relatively important.

An alternative explanation for the difference in our findings might be the difference in empirical design. In regressions 3 and 4 of Table 7 we consider how our results change were we to consider the effects of changes in corporate taxation on entry or exit alone, which we capture in our regressions by omitting the cross-terms from our estimating model. From this we find there is some sensitivity in our results for exit, but they work in the opposite direction to that found in the 
existing literature. For entry rates we continue to find a negative effect from increases in corporate taxation interacted with industry profitability during the short run. We now also find a similar effect for exit: a reduction in corporate taxation is found to increase exit rates, although the effect is only weakly significant. Taken at face value these results would appear to indicate somewhat counter intuitively that an increase in the corporate tax rate reduces the number of firms in an industry by reducing entry rates but increases the number of firms by reducing the rate at which firms close down. A more plausible explanation is provided by the role that the cross-equation terms play in regressions 1 and 2. A reduction in corporate tax rates leads entry rates to rise. Some of these additional firms either die relatively quickly, or displace older firms, which in turn causes a rise in exit rates. When not controlling for entry rates in the exit regression this effect appears as a negative coefficient on the corporate tax variable. We conclude from this evidence that controlling for the joint determination of entry and exit rates is important when evaluating the effects of policy changes on entrepreneurship.

\subsection{Robustness Tests}

For our results to suggest causal relationships our identification strategy also requires that 1) our results do not simply reflect trends in entry and exit across more or less profitable industries; 2) no other industry characteristic is relevant (the effects of tax changes are fully captured by industry profitability); 3) that there are no other policy variables that are omitted from the regression and which differ in their effects on entry and exit according to the profitability of the industry; and 4) a simultaneous relationship does not exist between entry/exit and tax policy.

\subsubsection{Placebo Tests}

To understand whether our tax variables simply capture differences in the underlying profitability of the industry (point 1) we use a falsification test. If the effect captured by tax variables in regressions 1 and 2 of Table 7 were simply related to industry trends, they were not causal, we would expect the coefficient on years prior to the tax-reform to be as large and significant as that in which the tax change occurs. To implement this we take the observed change in taxation and bring it forward by one year. The change in corporate tax rates in Italy in 1999 now occur in these new regressions in 1998 instead for example. We report the results from this exercise in regressions 5 and 6 of Table 7. We find no evidence for such effects: neither entry nor exit rates are affected. This suggests that the change in entry and exit rates which we capture appear to be specific to the year in which the corporate tax rate changed. 


\subsubsection{Other Industry Factors}

We test the robustness of our results to point 2) in Table 8 by considering the possibility that there are other changes to policy that are coincident to the tax reforms of interest but favour industries because they are human capital or ICT intensive. This tendency to favour the expansion of human capital and ICT intensive sectors of the economy appears to be widespread amongst policy makers, they can be found in many policy documents by the European Commission for example. ${ }^{23}$ Corporate tax rates have also been reduced over time because of a desire to attract foreign multinationals (Devereux and Griffith, 1998) and equally to discourage domestic firms from offshoring. Entry and exit rates may therefore be linked with tax policy changes by the trend towards increasing globalisation. We would anticipate that the effects of this are likely to be weakest in industries where offshoring is more difficult, which we measure by the openness of a sector to international trade.

The broad conclusion from Table 8 would appear to be that such factors have little bearing upon the entrepreneurship-corporate tax relationship in Table 7. Conditional on the change in corporate income taxation-profitability variable, we find that entry or exit rates are unaffected by changes in corporate taxation in industries that are more human capital, ICT intensive or more open to international trade. ${ }^{24}$ In contrast, we continue to find that changes in corporate income taxation interacted with industry profitability are statistically significant in the entry regressions reported in Table 8.

\section{[Insert Table 8]}

\subsubsection{Other Policy Changes or Country Specific Factors}

Our inclusion of country-time effects in the regression was motivated by a desire to control for the possible effects of other difficult to observe (non-tax) policy changes or political factors that might correlated with the timing of corporate tax rates of interest and the error term from the regression. To identify the effects of changes in corporate tax rates we instead exploited differences in their effect across industries. It remains possible that these difficult to observe non-tax policies also differ in their effect with industry profitability of course and these are correlated with the corporate tax changes we use and it is these effects that we identify in our regressions. Such a possibility is difficult to completely rule out. We try to address whether such effects are present in the data in Table 9 where we add to the regression an interaction between (time invariant US) corporate taxation-industry profitability and government expenditures (regressions 1 and 2),

23 The data for ICT and human capital are again for the US for the year 2000 but are from the EU KLEMS database.

24 We find similar insignificance for changes in the top statutory income tax rate interacted with industry human capital or ICT intensity. We choose not to report these regressions but are available from the authors on request. 
government revenues (regressions 3 and 4), whether a left-wing or right wing party holds political office (regressions 5 and 6) and the extent of fractionalisation (the number of coalition partners) within the ruling government (regressions 7 and 8). In the regressions controlling for government expenditures and revenues we assume that the potential non-tax policy changes generate some expenditure or revenue change, where we use total expenditures and revenues to capture as many as possible non-tax policy changes. In regressions 5 to 8 we try to control for the possibility that these difficult to observe policy changes are more likely in countries with particular types of government.

Again the addition of these new interaction terms does not affect the corporate tax variable of interest, although there is a decline in the magnitude of the coefficient when we add the political interactions term in regression 7 . We continue to find that an increase in corporate tax rates is associated with a decline in the rate of entry of firms and no change in the rate of exit. The interaction terms for government expenditures, revenues and left wing government are themselves, all statistically insignificant. There does appear to be an effect from government fractionalisation however, where we find that as this increases the rate of firm entry significantly decreases and the rate of exit increases.

\section{[Insert Table 9]}

\subsubsection{Instrumental variables}

\section{[Insert Table 10]}

The fiscal response to the recent macroeconomic crisis included temporary tax-cuts early on, followed by emergency tax rises in response to growing fiscal deficits. This reveals that tax rates are often adjusted in response to the macroeconomic shocks faced by a country. At present these factors are controlled for by the country-year dummies and market access variables in the estimating equation. However, as the UK experience demonstrates, governments may leverage tax policy to rebalance the economy by favouring certain sectors..$^{25}$ A simultaneous relationship may therefore exist such that our previous estimates are not free of endogeneity bias.

One solution to this problem requires the identification of a set of instruments that affect the timing and size of any tax changes, but not the rate of entry/exit by firms within a countryindustry. We draw upon a) the tax competition literature and b) factors identified by the political economy as influencing tax policy. Devereux et al. (2008) outline a model in which multinational firms choose their capital stock based upon the effective marginal tax rate they face and

${ }^{25}$ In the case of the UK, policy makers have sought to encourage entry in sectors outside the financial services industry in order to make the country less susceptible to shocks in the banking sector 
simultaneously decide upon location of their profits in response to differences in statutory tax rates between countries. They find evidence that OECD countries compete over effective marginal tax rates for capital and over statutory rates for profit but that these effects are only present between open countries. Moreover, the reductions in equilibrium tax rates they observe can be explained almost entirely by more intense competition between countries due to the relaxation of capital controls. We therefore calculate the average tax rates of neighbour countries and use this as an instrument (excluding the country itself). ${ }^{26}$ The instrument therefore varies across time and across countries, because of changes in neighbours' corporate tax rates.

We also draw upon the World Bank Database of Political Institutions, which has been extensively used in the political economy literature. We take the majority of the government (government majority), a measure of government stability (government stability), the longest tenure of a veto player (veto tenure) and a dummy equal to 1 if a legislative election was held in country $i$ during year $t$ (election), 0 otherwise, from this source. ${ }^{27}$

We report the results of our instrumental variable estimates for entry and exit in regressions 1 and 2 of Table 10. Qualitatively, the results are unchanged compared to beforehand: high corporate tax rates significantly reduce entry rates but do not affect exit. For this instrumental variable approach to be valid requires that the instruments are correlated with the profitability-corporate tax rate interaction, but not with industry entry or exit rates (other than through their effect on the endogenous variable). The diagnostic tests reported in the table indicate that the instruments appear relevant: the Cragg-Donald and Kleibergen-Paap F statistics comfortably exceed the 'critical' threshold value of 10 . Moreover, the first-stage regression output is in line with previous evidence. The race to the bottom in European tax rates during recent history suggests that governments are less likely to change the corporate tax rate when neighbouring countries levy high rates. Governments with large majorities are less likely to change corporate tax rates, possibly because they do not need to pander to the electorate to remain in office. We also find government stability and the length of tenure of the longest serving veto player to be positively correlated with the profitability-corporate tax rate interaction. Finally, we do not find that changes to tax policy occur disproportionately during election years.

A second requirement for this approach to be valid is that the instruments are uncorrelated with the second-stage error term. The Sargan overidentification test in both regressions indicates that the assumption of instrument exogeneity is satisfied.

\footnotetext{
26 The results are robust if we use distance weighted tax rates for other European countries; all OECD countries; or the average tax rates of neighbour countries as an instrument.

27 Similar instruments are used by Da Rin et al. (2011) in their study of entry through incorporation.
} 


\subsection{Personal Income Taxation}

Our data on entry and exit rates includes sole-proprietors, partnerships and forms of limited liability firms, all of which are, or can be, subject to personal income taxation. ${ }^{28}$ Gentry and Hubbard (2000) have previously shown that income tax rates negatively affect the probability of becoming self-employed. In this section we test for the effect of different marginal tax rates on personal income. In regressions 1 and 2 of Table 11 we begin by replacing the change in the corporation tax rate variable with the change in the top rate of personal income taxation. We find that while the effects of changes in this measure of personal income taxation are negatively correlated with entry rates, the effect is not significant at conventional levels. ${ }^{29}$ This result is unchanged when we include the corporate tax rate in the estimating equation, the results from which we report as regressions 5 and 6 in the table. ${ }^{30}$ These results match closely those found for a cross-section of 62 countries and the same measure of personal income taxation in Djankov et al. (2010). In regressions 3 and 4 of Table 11 we repeat the falsification test used in Table 7 to examine the robustness of our findings to the inclusion of future personal income tax rate changes. Our results are again found to be robust to this change. ${ }^{31}$

\section{[Insert Table 11]}

We next consider whether the top rate of income taxation used previously was not sufficiently detailed to capture the tax rate applied at different points in the income distribution. There are good reasons to believe that this might be the case: Gentry and Hubbard (2004) generate predictions about the impact of changes in the marginal income tax rate at different points in the income distribution upon a risk neutral individual's choice between self-employment and wage income. Our results, reported in Table 12, show that increases in the marginal tax rate applied at low income levels (67\% of average wages) reduce the level of entrepreneurship that takes place, whereas changes in the marginal personal income tax rate applied at or above $100 \%$ of average wages are associated with an increase in entry. For exit rates we find the opposite relationships: an increase in the tax paid by individuals with below average wages increases the exit rate, whereas those paid by individuals with above average wages $(167 \%)$ are associated with a decrease in exit rates, although

\footnotetext{
28 In the US for example limited liability partnerships can choose between paying personal or corporate income taxation. 29 An alternative viewpoint would be that industry profitability is not the relevant moderating variable: where selfemployment is more common wage income is of greater relevance than profits. We consider this second possibility by replacing the industry profitability variable with the average wage paid in the industry. Again we rely upon data from the US in 2000 to avoid endogeneity and simultaneity problems. We find however, that the results are unaffected by this change.

30 We might also use the results from this table to argue that the insignificance of the measure of personal income taxation suggest that the results for corporate taxation are not driven by some omitted time-varying country-industry variable that is also positively correlated with changes in corporate taxation.

${ }^{31}$ In unreported regressions we conducted a falsification test with changes in future corporate and personal income tax rate included simultaneously in the regressions. Our results were robust to this modification: future tax rate changes were not found to affect entry or exit rates in the current period.
} 
only the effect at higher income levels is statistically significant. Again there would appear to be a difference in the effects of taxation on existing versus new entrepreneurs. Altogether our findings are that increases in personal income taxation for incomes at or above average wages leads to increased entry rates, whereas the opposite happens for taxation on those with below the average wage. ${ }^{32}$ We continue to find that higher corporate taxation leads to lower entry rates. These results hold irrespective of whether the tax variables are included one at a time in Table 12, or as in the final columns (regressions 7 and 8) all at once.

\section{[Insert Table 12]}

The results we find are similar to those found for the US by Blau (1987), although he comments that the negative coefficient on tax rates at low income levels in his regression of the share of selfemployed as being 'puzzling'. To explain the positive coefficient on personal income taxation at higher income levels he refers to the increased incentives to under-report income, which is easier to do when self-employed. He further notes that these would appear capable of explaining some of the effects caused by tax changes at higher income levels, but not those for lower levels. For example, Anderson (1977), Pencavel (1979) and Cowell (1985) develop a link between higher taxation (and the punishments for tax evasion) with the occupational choice of individuals. Higher tax rates encourage individuals to move into self-employment, which is included within our measure of entry and exit, in order to reduce their tax burden. Broadly there may be seen to be two channels through which the self-employed lower their effective marginal tax rate. First, spending on plant and machinery, fittings and furnishings and energy consumption may be used to offset taxes but other personal expenditures such as mortgage interest payments may also be deemed to be tax deductible (Lang et al., 1997). ${ }^{33}$ The extent of underreporting of income by the self-employed has been found to vary across countries but estimates of the extent of underreporting have been found to lie in the interval between 11\% and 55\% (Pissarides and Weber, 1989; Apel, 1994; Lang et al., 1997; Johansson, 2000; Schuetze, 2002; Engstrom and Holmlund, 2009).

The reasons behind the negative effect of personal income tax rates on entry at $67 \%$ of average wages are more difficult to explain. We note however, that individual-level micro data contained within the British Household Panel Survey reveals that over the period 2000-2005, the average income of a self-employed person in the UK was between $65 \%$ and $78 \%$ of average wages. For those that had just entered self-employment, the corresponding figures were between $56 \%$ and $61 \%$.

\footnotetext{
32 This result remains when we include the interaction between the top rate of income taxation and profitability used previously.

${ }^{33}$ In the United Kingdom where a self-employed person runs their business from home they can deduct the business share of the rent, rates, heat, lighting, repairs and insurance costs from their tax bill. Similar deductions are available where motoring expenses are incurred for business purposes.
} 
Even 5 years after entering the average self-employed income was $76 \%$ of average wages during the period. ${ }^{34}$ It would therefore appear that for many of the individuals deciding on whether to enter through self-employment, the relevant marginal tax rate is likely to be that levied at the lower end of the income distribution (in the short-run at least). Increases in the marginal income tax rate at $67 \%$ of average wages may therefore decrease entry rates by dissuading some individuals from entering self-employment, assuming that the returns to self-employment are similar across countries as in the UK.

To provide some perspective on the effects of changes in personal income taxation on entrepreneurship dynamics we consider the effect of the same sized change in taxation used to construct Figure 3 (i.e. a tax cut of 2.4 percentage points). In Figure 4 we display the effect on the rate of entry for the personal income tax rate at $67 \%$ of the average wage. A reduction in this personal income tax rate has the effect of increasing the rate of entry in this model, where these effects are larger for more profitable industries. As suggested by the coefficient estimates we find that for the same sized change in tax rates the change in entry rates are quantitatively similar to those found for the corporate tax rate. The increase in entry is around 1 percentage point in the first year in an industry at the $90^{\text {th }}$ percentile of the profitability distribution, compared to 0.56 for an industry with a median level of profitability and 0.48 for an industry with profitability at the $10^{\text {th }}$ percentile. For the most profitable industries we estimate the entry rate will alter by as much as 1 percentage point in year 1 . As with corporate taxation we find these effects quickly die away.

[Insert Figure 4]

These effects are larger than for the same sized change in marginal tax rates at other values of average wages. An increase in the tax rate at the mean level of average wages is associated with a decline in entry of 0.11 percentage points for the industry with mean profitability $(-0.17$ for an industry at the $90^{\text {th }}$ percentile of profitability) and a decline in entry of 0.13 percentage points for the industry with mean profitability $\left(-0.19\right.$ for an industry at the $90^{\text {th }}$ percentile of profitability) when the personal tax rate at $167 \%$ of average wages is altered. For this latter tax rate, exit rates also increase by 0.30 percentage points for the industry with mean profitability ( -0.45 for an industry at the $90^{\text {th }}$ percentile of profitability). These estimated changes in entry and exit rates are small compared to the annual rate of entry and exit experienced in many industries.

\section{Conclusions}

34 These figures largely reflect the type of occupations in which the self-employed are engaged. OECD data show that the most common occupations among the self-employed are construction workers, taxi and truck drivers and farmers. 
Entrepreneurship has long been recognised by policy makers as an important source of employment, output and productivity growth as well as innovation. In this paper we consider the effect of one aspect of the policy environment, tax policy, on one key measure of entrepreneurship, the rate of firm entry and exit. Concerned by possible endogeneity bias caused by the omission of empirically relevant variables that are correlated with the timing of tax changes we undertake this empirical exercise using a difference-in-difference strategy for 19 countries and 28 industries from 1998 to 2005.

We find a number of new findings from this exercise (summarised in the table below). Firstly, the adjustment to the total stock of enterprises from tax reforms does not occur from symmetric changes to the rate of entry and exit of firms. As shown in the table below the entry margin is much more sensitive than the exit margin. Existing enterprise owners respond very little to tax changes in our data. Second, while the effects of corporate taxation on entry rates are consistently found to be negative, those for personal income taxation depend on which marginal tax rate is altered. Increases in personal tax rates applied at low income levels are found to discourage additional entry, whereas those applied to higher income levels encourage entrepreneurship. The estimated magnitude of the relationship with taxation and entry rates that we estimate is quantitatively similar to those found in the previous literature on this topic, while there is some difference from those studies on exit using micro data. That we use a broader measure of entrepreneurship suggests that the extent tax changes causes substitution between different enterprise types in order to avoid taxation is a relatively unimportant phenomenon for new entrants but is important for existing enterprise owners. Together this evidence suggests that incorporating asymmetries in the effects of taxation between existing and prospective entrepreneurs in future theoretical models on this topic would be a useful exercise.

\section{Summary of Results}

\begin{tabular}{lll} 
Marginal Tax Rates & Entry Rate & Exit Rate \\
\hline$\Delta$ corporate tax rate & - & 0 \\
$\Delta$ personal inc tax at $67 \%$ of & - & 0 \\
\hline
\end{tabular}


average wages

$\Delta$ personal inc tax at $100 \%$ of

$+$

average wages

$\Delta$ personal inc tax at $167 \%$ of $\quad+$

average wages

$\Delta$ top personal inc tax rate

0

0

Notes: +/- indicates statistical significance, 0 denotes effect was not significant. 


\section{References}

Aghion, P. and Howitt, P. (1992). 'A model of growth through creative destruction', Econometrica, Vol. 60, pp. 323-351.

Anderson, P. (1977). 'Tax evasion and labour supply', Scandinavian Journal of Economics, Vol. 79, pp. 375-383.

Angrist, J.D. and Pischke, J.-S. (2009). Mostly Harmless Econometrics. Oxford: Princeton University Press.

Apel, M. (1994). 'An Expenditure-Based Estimate of Tax Evasion in Sweden', Essays on Taxation and Economic Behaviour, Economic Studies 18, Department of Economics, Uppsala University.

Appelbaum, E., and Katz, E. (1996). 'Corporate Taxation, Incumbency Advantage and Entry,' European Economic Review, Vol. 40, pp.1817-28.

Aw, B-Y., Chen, X. and Roberts, M.J. (1997). 'Firm-level Evidence on Productivity Differentials, Turnover, and Exports in Taiwanese Manufacturing', NBER Working Papers 6235, National Bureau of Economic Research

Baldwin, J., and Gu, W. (2002). 'Plant Turnover and Productivity Growth in Canadian Manufacturing', PECD Science, Technology and Industry Working Papers, 2002/2 OECD Publishing.

Barnes, M. and J. Haskel (2002). "The Sources of Productivity Growth: Micro-Level Evidence for the OECD", National Statistics: Productivity Workshop 2002.

Bartelsman, E. and Doms, M. (2000). 'Understanding Productivity: Lessons from Longitudinal Microdata', Journal of Economic Literature, 38(3), pp. 569-594

Bartelsman, E, Scarpetta, S and Schivardi, F. (2005). 'Comparative analysis of firm demographics and survival: eveidence from micro-level sources in OECD countries', Industrial and Corporate Change, Vol. 14, pp. 365-391.

Bartelsman, E., Haltiwanger, J., and Scarpetta, S. (2005). 'Microeconomic Evidence of Creative Destruction in Industrial and Developing Countries', Tinbergen Institute Discussion Papers 04-114/3. Tinbergen Institute.

Bartelsman, E., Haltiwanger, J., and Scarpetta, S. (2009). 'Measuring and analyzing cross-country differences in firm dynamics', in Producer Dynamics: New Evidence from Micro Data, eds. Dunne, T., Jensen, B., and Roberts, M., University of Chicago Press, Chicago., pp. 15-76.

Blau. D. M., (1987). 'A Time-Series Analysis of Self-Employment in the United States', The Journal of Political Economy, Vol. 95, pp. 445-467

Bruce, D. (2002). 'Taxes and Entrepreneurial Endurance: Evidence from the Self-Employed', National Tax Journal, 54(1), pp. 5-24.

Bruce, D. and Mohsin. M. (2006). 'Tax Policy and Entrepreneurship: New Time Series Evidence', Small Business Economics, Vol. 26, pp. 409-425.

Burke, A, Fok, T., Thurik, R., and van Stel, A. (2009). 'The Dynamics of Entry and Exit Scales', Research Reports H200907, EIM Business and Policy Research

Caliendo, M., Fossen, F.M. and Kritikos, A.S. (2009). 'Risk Attitudes of Nascent Entrepreneurs New Evidence from an Experimentally Validated Survey', Small Business Economics, vol. 32, pp. 153-167. 
Gurley-Calvez, T. and Bruce, D. (2008). 'Do tax cuts promote entrepreneurial longevity', National Tax Journal, Vol. 61, pp. 225-250.

Campa, J. (2004). 'Exchange rates and trade: how important is hysteresis in trade?' European Economic Review, Vol.48, pp. 527-548.

Carroll, R., Holtz-Eakin, D., Rider, M. and Rosen, H.S. (1998). 'Entrepreneurs, income taxes, and investment', NBER Working Paper, No. 6374.

Cowell, F. (1985). 'Tax evasion with labour income', Journal of Public Economics, Vol. 26, pp. 19-34.

Cullen, J., and Gordon, R.H. (2007). 'Taxes and Entrepreneurial Risk-Taking: Theory and Evidence for the U.S.', Journal of Public Economics, Vol. 91, pp. 1479-1505.

Da Rin, M., Di Giacomo, M., and Sembenelli, A. (2010). 'Corporate Taxation and the Size of New Firms: Evidence from Europe', Journal of the European Economic Association, 8(2-3), pp. 606616.

Da Rin, M., Di Giacomo, M., and Sembenelli, A. (2011). 'Entrepreneurship, Firm Entry, and the Taxation of Corporate Income: Evidence from Europe', Journal of Public Economics, 95(9-10), pp. 1048-1066.

Devereux, M.P. and Griffith, R. (1998). 'Taxes and the Location of Production: Evidence from a Panel of US Multinationals', Journal of Public Economics, 68(3), pp. 335-367

Disney, R., Haskel, J. and Heden, Y. (2003). 'Restructuring and Productivity Growth in UK Manufacturing', Economic Journal, Vol. 113, pp. 666-694.

Djankov, S. (2009). 'The regulation of entry: A survey', The World Bank Research Observer, Vol. 24, pp. 183-203.

Djankov, S., Ganser, T., McLiesh, C., Ramalho, R. and Schleifer, A. (2010). ' The Effect of Corporate Taxes on Investment and Entrepreneurship', American Economic Journal: Macroeconomics, Vol. 2, pp. 31-64.

Engstrom, P. and Holmlund, B. (2009). 'Tax evasion and self-employment in a high-tax country: evidence from Sweden', Applied Economics, 41, pp. 2419-2430.

Eurostat-OECD (2007). 'Manual on Business Demography Statistics', downloaded from http://www.oecd.org/dataoecd/8/8/39974460.pdf January 152011.

Foster, L., J. Haltiwanger and C. J. Krizan (1998). 'Aggregate Productivity Growth: Lessons from Microeconomic Evidence', NBER Working Paper Series, Working Paper No. 6803.

Foster, L., Haltiwanger, J., and Krizan, C., (2001). 'Aggregate Productivity Growth Lessons from Microeconomic Evidence', NBER Chapters in: New Developments in Productivity Analysis, pp. 303-372.

Gentry, W., and Hubbard, R.G. (2000). 'Tax Policy and Entrepreneurial Entry', American Economic Review, Vol. 90, pp. 283-287.

Gentry, W., and Hubbard, R.G. (2004). 'The Effects of Progressive Income Taxation on Job Turnover', Journal of Public Economics, Vol. 88, pp. 2301-2322.

Geroski, P.A., (1995). 'What do we Know About Entry?', International Journal of Industrial Organization, Vol. 13, pp. 421-440.

Gordon, R. (1998). 'Can High Personal Tax Rates Encourage Entrepreneurial Activity?' IMF Staff Papers, Vol. 45, pp. 49-80. 
Hanson, G. (2005). 'Market Potential, Increasing Return and Geographic Concentration', Journal of International Economics Vol. 67, pp. 1-24

Harris, C.D. (1954). 'The Market as a Factor in the Localization of Production', Annals of the Association of American Geographers, Vol. 44, pp. 315-348.

Head, K., Mayer, T., and Ries, J. (2009). 'How Remote is the Offshoring Threat?', European Economic Review, Vol. 53, pp. 429-444.

Holtz-Eakin, D., Rosen, H., and Weathers, R. (2000). 'Horatio Alger Meets the Mobility Tables,' Small Business Economics, Vol. 14, pp. 243-74.

Hopenhayn, H.A. (1992). 'Entry, exit, and firm dynamics in the long run', Econometrica, Vol. 60, pp. $1127-1150$.

Johansson, E. (2000). 'An Expenditure Based Estimation of Self-Employment Income Underreporting in Finland', Working Paper 433, Swedish School of Economics and Business Administration, Helsinki.

Kessides, I. (1991). 'Entry and Market Contestability: The Evidence from The UK', in P.A. Geroski and J. Schwalbach (eds), Entry and Market Contestability: An International Comparison, Blackwell, Oxford.

Kihlstrom, R.E. and Laffont, J.J. (1979). 'A General Equilibrium Entrepreneurial Theory of Firm Formation Based on Risk Aversion', Journal of Political Economy, vol. 87(4), pp. 719-748.

Klapper, L., Laeven, L. and Rajan, R. (2006). 'Entry regulation as a barrier to entrepreneurship', Journal of Financial Economics, Vol. 82, pp. 591-629.

Kneller, R., Pisu, M., and Yu, Z. (2008). 'Overseas Trading Costs and Firm Export Performance', Canadian Journal of Economics, Vol. 41, pp. 639-669.

Lang, O., Nöhrbaß, K.-H. and Stahl, K. (1997). ' On income tax avoidance: the case of Germany', Journal of Public Economics, 66, pp. 327-347.

Long, J. E. (1982). 'The taxation of self-employment', National Tax Journal, Vol. 35, pp. 31-42.

Manjon-Antolin, M. C. (2010). 'Firm Size and Short-Term Dynamics in Aggregate Entry and Exit', International Journal of Industrial Organization, 28(5), pp. 464-476.

Manova, K., Wei., S.-J. and Zhang, Z. (2011). ‘Firm Exports and Multinational Activity under Credit Constraints', NBER Working Paper 16095

Nunn, N. (2007). 'Relationship-Specificity, Incomplete Contracts and the Pattern of Trade', Quarterly Journal of Economics, 122(2), pp. 569-600.

OECD (2009). 'Measuring entrepreneurship: A collection of Indicators. 2009 Edition', Entrepreneurship Indicators Project

Papke, L.E. (1991). 'Interstate business tax differentials and new firm location: Evidence from panel data', Journal of Public Economics, Vol. 45(1), pp. 47-68

Pencavel, J. (1979). 'A note on income tax evasion, labour supply and nonlinear tax schedules', Journal of Public Economics, Vol. 25, pp. 160-169.

Pissarides, C. and Weber, G. (1989). 'An Expenditure-Based Estimate of Britain's Black Economy', Journal of Public Economics, 39, pp. 17-32.

Rajan, R. and Zingales, L. (1998). 'Financial dependence and growth'. American Economic Review, Vol. 88, pp. 559-586. 
Roberts, M. and Tybout, J. (1997). 'Producer Turnover and Productivity Growth in Developing Countries', The World Bank Research Observer, February.

Robson, M. and Wren, C. (1999). 'Marginal and average tax rates and the incentive for selfemployment', Southern Economic Journal, Vol. 65, pp. 757-773.

Romer, P. (1990). 'Endogenous technical change', Journal of Political Economy, Vol. 98, pp. 71-102.

Scarpetta, S., Hemmings, P., Tressel, T. and Woo, J. (2002). 'The Role of Policy and Institutions from Productivity and Firm Dynamics: Evidence from Micro and Industry Data', OECD Economics Department Working Papers 329.

Schuetze, H. (2002). 'Profiles of Tax Noncompliance among the Self-Employed in Canada: 19691992', Canadian Public Policy, 28, pp. 219-238.

Schwalbach, J. (1991). 'Entry, exit, concentration and market contestability', in P. Gersoki and J. Schwalbach (eds), Entry and market contestability: An international comparison, Blackwell, Oxford.

Sleuwaegen, L,. and Dehandschutte, W. (1991). 'Entry and Exit in Belgian Manufacturing', in P.A. Geroski and J. Schwalbach (eds.), Entry and Market Contestability: An International Comparison, Blackwell, Oxford.

Stabile, M. (2004). 'Payroll Taxes and the Decision to be Self-Employed', International Tax and Public Finance, Vol. 11, pp. 31-53.

Taylor, M.P. (1999). 'Survival of the Fittest? An Analysis of Self-Employment Duration in Britain', Economic Journal, 109, pp. 140-155.

World Bank (2008). 'Doing Business', Washington D.C. 


\section{Tables and Figures}

Table 1. Coverage of Entry-Exit Data by Data Source

\begin{tabular}{lcc}
\multicolumn{1}{c}{ Industry } & Manufacturing & Services \\
& & \\
Belgium & $98-99$ & $98-99$ \\
Czech Republic & $01-04$ & $01-04$ \\
Estonia & & \\
Finland & $98-04$ & $98-04$ \\
France & $03-05$ & $03-05$ \\
Germany & $03-05$ & $03-05$ \\
Hungary & $00-05$ & \\
Italy & $98-05$ & $98-04$ \\
Latvia & $00-05$ & \\
Lithuania & $00-02$ & \\
Luxembourg & $98-04$ & $98-04$ \\
Netherlands & $99-04$ & $00-04$ \\
Norway & $99-01$ & $99-01$ \\
Portugal & $98-05$ & $98-04$ \\
Slovakia & $00-04$ & $00-04$ \\
Slovenia & $00-05$ & $00-04$ \\
Spain & $98-05$ & $98-05$ \\
Sweden & $98-05$ & $98-05$ \\
United Kingdom & $98-05$ & $98-05$ \\
\hline Notes: All data are from the OECD-Eurostat Structural and \\
Demographic Business Statistics Database. Manufacturing \\
refers to SIC codes 15-36 and services to SIC codes 50-74.
\end{tabular}


Table 2. Average Rate of Entry and Exit by Country and Broad Sector Manufacturing Services

Measure Rate of Entry Rate of Exit Rate of Entry Rate of Exit

Country

\begin{tabular}{lcccc}
\hline & & & & \\
Belgium & 5.07 & 5.50 & 9.49 & 8.13 \\
Czech Republic & 8.27 & 8.55 & 11.09 & 10.39 \\
Estonia & 8.26 & 7.68 & & \\
Finland & 5.03 & 5.66 & 8.17 & 6.94 \\
France & 5.25 & 5.83 & 10.15 & 7.03 \\
Germany & 5.70 & 5.72 & 11.27 & 10.71 \\
Hungary & 6.59 & 7.92 & & \\
Italy & 5.49 & 5.65 & 9.72 & 7.53 \\
Latvia & 10.58 & 7.89 & & \\
Lithuania & 9.30 & 7.76 & & 8.87 \\
Luxembourg & 5.57 & 5.01 & 13.04 & 9.69 \\
Netherlands & 5.52 & 6.23 & 10.05 & 8.28 \\
Norway & 5.88 & 6.20 & 13.36 & 8.99 \\
Portugal & 7.07 & 6.13 & 9.31 & 6.35 \\
Slovakia & 8.46 & 7.49 & 10.88 & 6.52 \\
Slovenia & 4.38 & 5.27 & 9.17 & 11.13 \\
Spain & 6.54 & 6.00 & 10.38 & 8.95 \\
Sweden & 4.68 & 4.61 & 6.77 & \\
United Kingdom & 8.35 & 9.84 & 12.23 & \\
All Countries & $\mathbf{6 . 9 3}$ & $\mathbf{6 . 6 4}$ & $\mathbf{1 1 . 2 5}$ & \\
\hline Notes: Data relates to 'all enterprises'. Manufacturing refers to SIC codes $15-36$ and \\
services to SIC codes 50-74. Entry and exit rates are expressed as percentage ratios of the \\
stock of remaining firms. & & & & \\
& & & &
\end{tabular}


Table 3: Corporate Tax Reforms

\begin{tabular}{|c|c|c|}
\hline Country & Year(s) of Tax Reform & Change in Statutory Corporate Income Tax Rate \\
\hline Belgium & 2003 & -0.06 \\
\hline Czech Republic & $1998,2000,2004,2005$ & $-0.04,-0.04,-0.03,-0.02$ \\
\hline Estonia & 2005 & -0.02 \\
\hline Finland & 2000,2005 & $0.01,-0.03$ \\
\hline France & $1999,2000,2001,2002,2005$ & $-0.017,-0.02,-0.01,-0.01,-0.004$ \\
\hline Germany & $1998,1999,2001,2003,2004,2005$ & $-0.007,-0.04,-0.13,0.01,-0.01,0.004$ \\
\hline Hungary & 2004,2005 & $-0.02,-0.001$ \\
\hline Italy & $1998,2001,2003,2004$ & $-0.119,-0.01,-0.02,-0.01$ \\
\hline Latvia & $2002,2003,2004$ & $-0.03,-0.03,-0.04$ \\
\hline Lithuania & 2002 & -0.09 \\
\hline Luxembourg & 1998,2002 & $-0.018,-0.071$ \\
\hline Netherlands & 2002,2005 & $-0.005,-0.03$ \\
\hline Portugal & $1998,2000,2002,2004$ & $-0.022,-0.022,-0.022,-0.055$ \\
\hline Slovakia & $2000,2002,2004$ & $-0.11,-0.04,-0.06$ \\
\hline United Kingdom & 1999 & -0.01 \\
\hline
\end{tabular}

Notes: Statutory corporate tax rates are from the Eurostat Taxation Trends in the EU. The years of tax reform are those that occur during the sample window of each country in Table 1. No tax reforms are found for Norway, Slovenia, Spain and Sweden during these time periods.

Table 4: Personal Income Tax Reforms (Top marginal tax rate)

\begin{tabular}{|c|c|c|}
\hline Country & Year(s) of Tax Reform & Change in Top Statutory Personal Income Tax Rate \\
\hline Belgium & $2001,2002,2003$ & $-0.005,-0.037,-0.027$ \\
\hline Czech Republic & 2000 & -0.08 \\
\hline Estonia & 2005 & -0.02 \\
\hline Finland & $1998,1999,2000,2001,2002,2003,2004,2005$ & $-0.017,-0.022,-0.016,-0.005,-0.01,-0.003$, \\
& & $-0.001,-0.011$ \\
\hline France & $1998,2001,2002,2003,2004,2005$ & $0.013,-0.007,-0.005,-0.03,-0.01,0.001$ \\
\hline Germany & $1998,2000,2001,2004,2005$ & $-0.011,-0.021,-0.026,-0.037,-0.032$ \\
\hline Hungary & 2001,2004 & $-0.04,-0.02$ \\
\hline Italy & $1998,2000,2002,2005$ & $-0.05,-0.001,0.002,-0.02$ \\
\hline Luxembourg & $1998,2001,2002$ & $-0.041,-0.041,-0.041$ \\
\hline Netherlands & 2001 & -0.08 \\
\hline Norway & $1999,2000,2005$ & $-0.002,0.06,-0.04$ \\
\hline Slovakia & 2002,2004 & $-0.04,-0.19$ \\
\hline Spain & 1999,2003 & $-0.08,-0.03$ \\
\hline Sweden & $1998,1999,2000,2001,2002,2003,2004,2005$ & $0.023,-0.031,-0.021,0.016,0.024,-0.008,0.018,0.001$ \\
\hline
\end{tabular}

Notes: Statutory top personal income tax rates are from the Eurostat Taxation Trend in the EU. The years of tax reform are those that occur during the sample window of each country in Table 1. No tax reforms are found for Austria,

Latvia, Lithuania, Portugal, Slovenia, and United Kingdom during these time periods.

Table 5: Personal Income Tax Reforms (OECD data)

\begin{tabular}{|c|c|c|c|c|c|c|}
\hline Country & $\begin{array}{l}\text { Change in Personal } \\
\text { Income Tax Rate at } \\
67 \% \text { of average wage }\end{array}$ & $\begin{array}{c}\text { Year(s) } \\
\text { of Tax Reform }\end{array}$ & $\begin{array}{l}\text { Change in Personal } \\
\text { Income Tax Rate at } \\
100 \% \text { of average wage }\end{array}$ & $\begin{array}{c}\text { Year(s) } \\
\text { of Tax Reform }\end{array}$ & $\begin{array}{l}\text { Change in Personal } \\
\text { Income Tax Rate at } \\
167 \% \text { of average wage }\end{array}$ & $\begin{array}{c}\text { Year(s) } \\
\text { of Tax Reform }\end{array}$ \\
\hline Belgium & -0.004 & 2001 & $-0.004,-0.004$ & 2001,2002 & $-0.004,-0.009,-0.021$ & $2001,2002,2003$ \\
\hline $\begin{array}{c}\text { Czech } \\
\text { Republic }\end{array}$ & & & & & $-0.044,0.044$ & 2001,2002 \\
\hline Finland & $\begin{array}{c}-0.001,-0.010 \\
-0.010,-0.010,-0.0004\end{array}$ & $\begin{array}{c}2001,2002,2003, \\
2004,2005\end{array}$ & $\begin{array}{c}-0.008,-0.009,-0.010,- \\
0.010,-0.005\end{array}$ & $\begin{array}{l}2001,2002,2003, \\
2004,2005\end{array}$ & $\begin{array}{c}-0.010,-0.010 \\
-0.010,-0.010,-0.005\end{array}$ & $\begin{array}{c}2001,2002,2003, \\
2004,2005\end{array}$ \\
\hline France & $\begin{array}{c}-0.0001,-0.001,-0.008,- \\
0.004,0.001\end{array}$ & $\begin{array}{c}2001,2002,2003 \\
2004,2005\end{array}$ & $\begin{array}{c}0.009,-0.009,-0.012,- \\
0.005,0.004\end{array}$ & $\begin{array}{l}2001,2002,2003, \\
2004,2005\end{array}$ & $\begin{array}{c}0.0004,-0.0004,-0.016,- \\
0.01,-0.001\end{array}$ & $\begin{array}{c}2001,2002,2003, \\
2004,2005\end{array}$ \\
\hline Germany & $\begin{array}{c}-0.015,0.004,0.004,- \\
0.009,-0.014 \\
\end{array}$ & $\begin{array}{c}2001,2002,2003 \\
2004,2005\end{array}$ & $\begin{array}{c}-0.009,0.006,0.005,- \\
0.010,-0.026 \\
\end{array}$ & $\begin{array}{c}2001,2002,2003, \\
2004,2005\end{array}$ & $-0.026,-0.037,-0.032$ & $2001,2004,2005$ \\
\hline Hungary & $-0.001,-0.019,-0.03$ & $2003,2004,2005$ & $-0.18,0.18,-0.001,0.001$ & $\begin{array}{c}2001,2002,2003, \\
2004\end{array}$ & $0.020,-0.021,0.001$ & $2002,2003,2004$ \\
\hline Italy & $-0.014,0.051$ & 2001,2003 & $-0.014,0.049,-0.070$ & $2001,2003,2005$ & 0.046 & 2001 \\
\hline Luxembourg & $\begin{array}{c}-0.018,-0.055,0.018, \\
0.017\end{array}$ & $\begin{array}{c}2001,2002,2003, \\
2005\end{array}$ & $\begin{array}{c}-0.018,-0.036,0.018, \\
0.018\end{array}$ & $\begin{array}{c}2001,2002,2003, \\
2005\end{array}$ & $0.384,-0.036,-0.001$ & $2001,2002,2005$ \\
\hline Netherlands & $\begin{array}{c}-0.003,0.003 \\
-0.013 .0 .008,0.014\end{array}$ & $\begin{array}{c}2001,2002,2003 \\
2004,2005\end{array}$ & $\begin{array}{c}-0.071,0.001 \\
-0.004,-0.0002\end{array}$ & $\begin{array}{c}2001,2002,2003, \\
2005\end{array}$ & 0.020 & 2001 \\
\hline Norway & $\begin{array}{c}-0.015,0.048,-0.019 \\
0.004,-0.004\end{array}$ & $\begin{array}{c}2001,2002,2003 \\
2004,2005\end{array}$ & $\begin{array}{c}-0.015,0.048,-0.019 \\
0.004,-0.139\end{array}$ & $\begin{array}{c}2001,2002,2003, \\
2004,2005\end{array}$ & $\begin{array}{c}-0.015,0.048,-0.019 \\
0.004,-0.019\end{array}$ & $\begin{array}{c}2001,2002,2003, \\
2004,2005\end{array}$ \\
\hline Portugal & $-0.01,-0.01$ & 2001,2005 & $-0.01,-0.005$ & 2001,2005 & -0.010 & 2001 \\
\hline Spain & $0.005,-0.048$ & 2002,2003 & $-0.009,-0.032$ & 2002,2003 & $-0.016,-0.033$ & 2002,2003 \\
\hline Sweden & $\begin{array}{l}-0.018,-0.018 \\
-0.012,-0.009\end{array}$ & $\begin{array}{c}2001,2002,2003, \\
2005\end{array}$ & $-0.014,-0.211,0.190$ & $2001,2002,2005$ & & \\
\hline
\end{tabular}

Notes: Personal income tax rates are from the OECD. The years of tax reform are those that occur during the sample window of each country in Table 1. No tax reforms are found for Estonia, Latvia, Lithuania, Slovakia, Slovenia, and United Kingdom during these time periods. 
Table 6: Partial Correlations Between Tax Rates

\begin{tabular}{|c|c|c|c|c|c|}
\hline & $\begin{array}{c}\text { Corporate tax } \\
\text { rate }\end{array}$ & $\begin{array}{c}\text { Top personal } \\
\text { income tax } \\
\text { rate }\end{array}$ & $\begin{array}{c}\text { Personal } \\
\text { income tax } \\
\mathbf{6 7 \%} \text { of av. } \\
\text { wage }\end{array}$ & $\begin{array}{c}\text { Personal } \\
\text { income tax } \\
\mathbf{1 0 0 \%} \text { of av. } \\
\text { wage }\end{array}$ & $\begin{array}{c}\text { Personal } \\
\text { income tax } \\
\mathbf{1 6 7 \%} \text { of av. } \\
\text { wage }\end{array}$ \\
\hline Corporate tax rate & 1 & 1 & & & \\
\hline $\begin{array}{c}\text { Top personal income } \\
\text { tax rate }\end{array}$ & $0.3598^{* *}$ & $-0.0494^{* *}$ & 1 & & \\
\hline $\begin{array}{c}\text { Personal income tax } \\
\mathbf{6 7 \%} \text { of av. Wage }\end{array}$ & $0.3098^{* *}$ & $-0.0027^{* *}$ & $0.1724^{* *}$ & 1 & \\
\hline $\begin{array}{c}\text { Personal income tax } \\
\mathbf{1 0 0 \%} \text { of av. Wage }\end{array}$ & $0.0027^{* *}$ & $0.2252+$ & $-0.0805^{* *}$ & $0.0120^{* *}$ & \\
\hline $\begin{array}{c}\text { Personal income tax } \\
\mathbf{1 6 7 \%} \text { of av. Wage }\end{array}$ & 0.2354 & & & \\
\hline
\end{tabular}

Notes: $+,{ }^{*},{ }^{* *}$ denote significance at the $10 \%, 5 \%$ and $1 \%$ levels respectively. 
Table 7: Relationship between entrepreneurship, corporate taxation and industry profitability

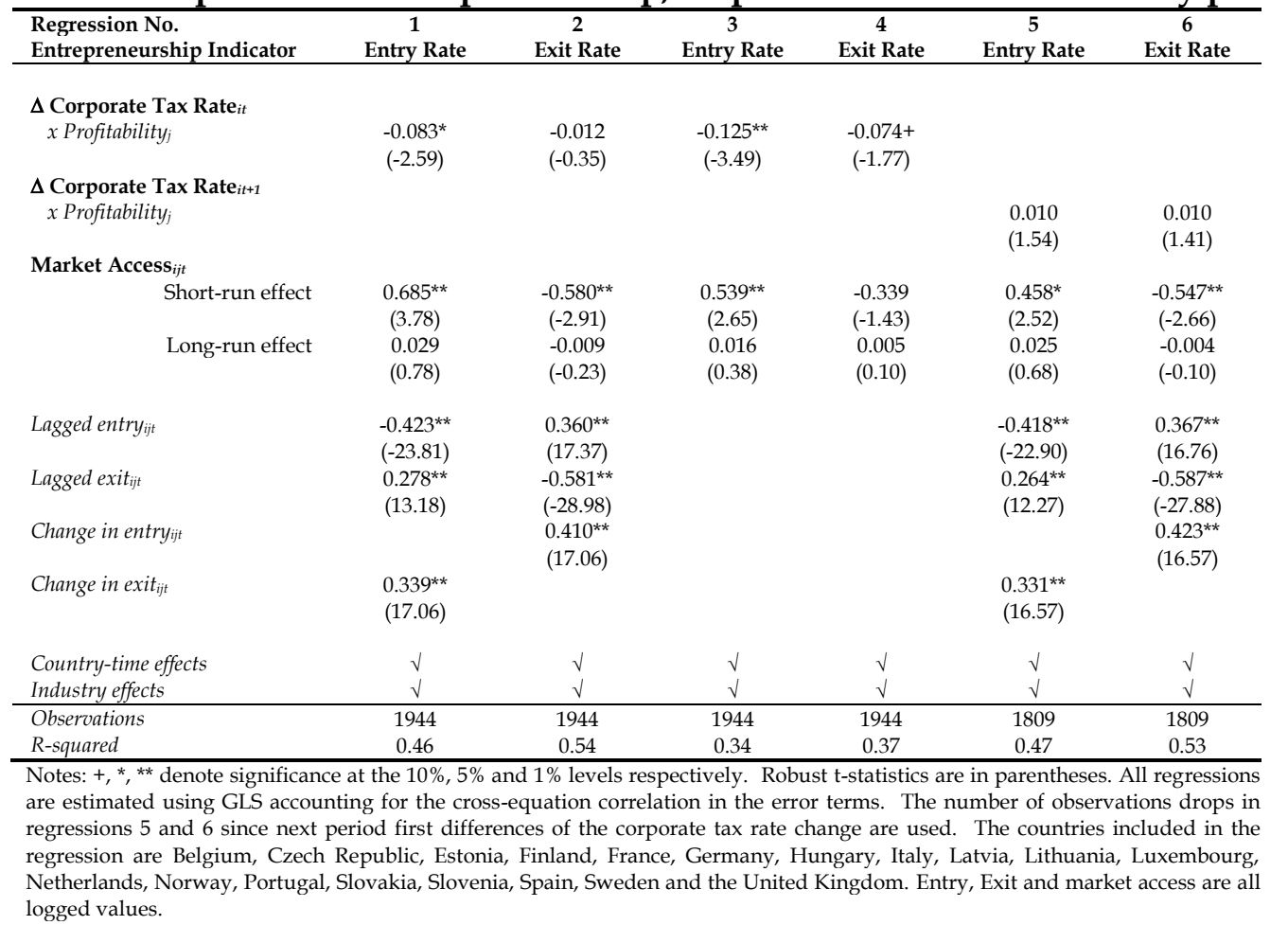


Table 8: Relationship between entrepreneurship, corporate income taxation and industry characteristics

\begin{tabular}{|c|c|c|c|c|c|c|}
\hline Regression No. & $\begin{array}{c}1 \\
\text { Entry Rate }\end{array}$ & $\begin{array}{c}2 \\
\text { Exit Rate }\end{array}$ & $\begin{array}{c}3 \\
\text { Entry Rate }\end{array}$ & $\begin{array}{c}4 \\
\text { Exit Rate }\end{array}$ & $\begin{array}{c}5 \\
\text { Entry Rate }\end{array}$ & $\begin{array}{c}6 \\
\text { Exit Rate }\end{array}$ \\
\hline \multicolumn{7}{|l|}{$\Delta$ Corporate Tax Rate $_{\text {it }}$} \\
\hline x Profitability & $\begin{array}{c}-0.086^{* *} \\
(-2.64)\end{array}$ & $\begin{array}{c}-.007 \\
(-0.18)\end{array}$ & $\begin{array}{l}-0.086^{* *} \\
(-2.62)\end{array}$ & $\begin{array}{l}-0.014 \\
(-0.39)\end{array}$ & $\begin{array}{l}-0.085^{* *} \\
(-2.65)\end{array}$ & $\begin{array}{l}-0.013 \\
(-0.36)\end{array}$ \\
\hline x Human Capital & $\begin{array}{l}1.356 \\
(0.51)\end{array}$ & $\begin{array}{l}-2.277 \\
(-0.78)\end{array}$ & & & & \\
\hline$x \mathrm{ICT}_{\mathrm{j}}$ & & & $\begin{array}{l}0.734 \\
(0.43)\end{array}$ & $\begin{array}{l}0.469 \\
(0.25)\end{array}$ & & \\
\hline x Openness $\mathrm{j}_{\mathrm{j}}$ & & & & & $\begin{array}{l}0.064 \\
(1.11)\end{array}$ & $\begin{array}{l}0.013 \\
(0.20)\end{array}$ \\
\hline \multicolumn{7}{|l|}{ Market Access $s_{\mathrm{ijt}}$} \\
\hline Short-run effect & $\begin{array}{c}0.680^{* *} \\
(3.74)\end{array}$ & $\begin{array}{c}-0.571^{* *} \\
(-2.85)\end{array}$ & $\begin{array}{c}0.681^{* *} \\
(3.75)\end{array}$ & $\begin{array}{c}-0.583^{* *} \\
(-2.91)\end{array}$ & $\begin{array}{c}0.695^{* *} \\
(3.83)\end{array}$ & $\begin{array}{c}-0.578^{* *} \\
(-2.89)\end{array}$ \\
\hline Long-run effect & $\begin{array}{l}0.028 \\
(0.76)\end{array}$ & $\begin{array}{l}-0.008 \\
(-0.19)\end{array}$ & $\begin{array}{l}0.029 \\
(0.78)\end{array}$ & $\begin{array}{l}-0.010 \\
(-0.23)\end{array}$ & $\begin{array}{l}0.031 \\
(0.84)\end{array}$ & $\begin{array}{l}-0.009 \\
(-0.22)\end{array}$ \\
\hline Lagged entry ${ }_{j i t}$ & $\begin{array}{l}-0.424^{* *} \\
(23.77)\end{array}$ & $\begin{array}{l}0.361^{* *} \\
(17.38)\end{array}$ & $\begin{array}{l}-0.424^{* *} \\
(-23.79)\end{array}$ & $\begin{array}{l}0.360^{* *} \\
(17.31)\end{array}$ & $\begin{array}{l}-0.422^{* *} \\
(-23.70)\end{array}$ & $\begin{array}{l}0.360^{* *} \\
(17.35)\end{array}$ \\
\hline Lagged exit $t_{j i t}$ & $\begin{array}{l}0.278^{* *} \\
(13.19)\end{array}$ & $\begin{array}{l}-0.581^{* *} \\
(-29.00)\end{array}$ & $\begin{array}{l}0.278^{* *} \\
(13.18)\end{array}$ & $\begin{array}{l}-0.581^{* *} \\
(-28.92)\end{array}$ & $\begin{array}{l}0.276^{* *} \\
(13.10)\end{array}$ & $\begin{array}{l}-0.581^{* *} \\
(-28.96)\end{array}$ \\
\hline Change in entry ${ }_{j i t}$ & & $\begin{array}{l}0.410^{* *} \\
(17.07)\end{array}$ & & $\begin{array}{l}0.410^{* *} \\
(17.05)\end{array}$ & & $\begin{array}{l}0.409^{* *} \\
(17.02)\end{array}$ \\
\hline Change in exit $t_{i j t}$ & $\begin{array}{l}0.339^{\star *} \\
(17.07)\end{array}$ & & $\begin{array}{l}0.339^{* *} \\
(17.05)\end{array}$ & & $\begin{array}{l}0.338^{* *} \\
(17.02)\end{array}$ & \\
\hline Country-time effects & $\checkmark$ & $\checkmark$ & $\sqrt{ }$ & $\sqrt{ }$ & $\sqrt{ }$ & $\sqrt{ }$ \\
\hline Industry effects & v & v & v & v & v & v \\
\hline Observations & 1944 & 1944 & 1944 & 1944 & 1944 & 1944 \\
\hline$R$-squared & 0.46 & 0.54 & 0.46 & 0.54 & 0.46 & 0.54 \\
\hline
\end{tabular}


Table 9: Robustness testing - Alternative fiscal variables

\begin{tabular}{|c|c|c|c|c|c|c|c|c|c|}
\hline \multicolumn{2}{|l|}{ Regression No. } & $\begin{array}{c}1 \\
\text { Entry Rate }\end{array}$ & $\begin{array}{c}2 \\
\text { Exit } \\
\text { Rate }\end{array}$ & $\begin{array}{c}3 \\
\text { Entry Rate }\end{array}$ & $\begin{array}{c}4 \\
\text { Exit } \\
\text { Rate }\end{array}$ & $\begin{array}{c}5 \\
\text { Entry } \\
\text { Rate }\end{array}$ & $\begin{array}{c}6 \\
\text { Exit Rate }\end{array}$ & $\begin{array}{c}7 \\
\text { Entry } \\
\text { Rate }\end{array}$ & $\begin{array}{c}8 \\
\text { Exit Rate }\end{array}$ \\
\hline \multicolumn{10}{|c|}{$\Delta$ Corporate Tax Rateit } \\
\hline \multicolumn{2}{|c|}{$x$ Profitability } & $\begin{array}{l}-0.082^{*} \\
(-2.48)\end{array}$ & $\begin{array}{l}-0.005 \\
(-0.13)\end{array}$ & $\begin{array}{l}-0.083^{*} \\
(-2.44)\end{array}$ & $\begin{array}{l}0.001 \\
0.04)\end{array}$ & $\begin{array}{l}-0.072^{*} \\
(-2.17)\end{array}$ & $\begin{array}{l}-0.002 \\
(-0.06)\end{array}$ & $\begin{array}{l}-0.073^{*} \\
(-2.22)\end{array}$ & $\begin{array}{l}-0.004 \\
(-0.09)\end{array}$ \\
\hline \multicolumn{2}{|c|}{$x$ Profitability $_{j} \times$ government expenditure $_{i t}$} & $\begin{array}{l}0.000 \\
(0.85)\end{array}$ & $\begin{array}{l}-0.000 \\
(-1.45)\end{array}$ & & & & & & \\
\hline \multicolumn{2}{|c|}{$x$ Profitability $_{j} \times$ government revenue $_{i t}$} & & & $\begin{array}{l}-0.000 \\
(-0.17)\end{array}$ & $\begin{array}{l}-0.000 \\
(-0.54)\end{array}$ & & & & \\
\hline \multicolumn{2}{|c|}{$x$ Profitability $_{j} \times$ left wing government $t_{i t}$} & & & & & $\begin{array}{l}-0.004 \\
(-0.63)\end{array}$ & $\begin{array}{l}0.001 \\
(0.15)\end{array}$ & & \\
\hline \multicolumn{2}{|c|}{$x$ Profitability $_{j} \times$ government factionalisation $_{i t}$} & & & & & & & $\begin{array}{l}-0.031^{*} \\
(-2.01)\end{array}$ & $\begin{array}{c}0.031+ \\
(1.87)\end{array}$ \\
\hline Market Access $s_{j \mathrm{jt}}$ & $\begin{array}{l}\text { Short-run effect } \\
\text { Long-run effect }\end{array}$ & $\begin{array}{l}0.662^{* *} \\
(3.77) \\
0.027 \\
(0.75)\end{array}$ & $\begin{array}{c}-0.573^{* *} \\
(-2.91) \\
-0.006 \\
(-0.15)\end{array}$ & $\begin{array}{c}0.661^{* *} \\
(3.76) \\
0.028 \\
(0.77)\end{array}$ & $\begin{array}{c}-0.571^{* *} \\
(-2.89) \\
-0.008 \\
(-0.20)\end{array}$ & $\begin{array}{c}0.681^{* *} \\
(3.75) \\
0.029 \\
(0.79)\end{array}$ & $\begin{array}{c}-0.579^{* *} \\
(-2.90) \\
-0.009 \\
(-0.23)\end{array}$ & $\begin{array}{c}0.694^{* *} \\
(3.83) \\
0.028 \\
(0.75)\end{array}$ & $\begin{array}{c}-0.589^{* *} \\
(-2.95) \\
-0.008 \\
(-0.20)\end{array}$ \\
\hline Lagged entry ${ }_{j i t}$ & & $\begin{array}{l}-0.396^{* *} \\
(-22.69)\end{array}$ & $\begin{array}{l}0.340^{* *} \\
(16.41)\end{array}$ & $\begin{array}{l}-0.396^{* *} \\
(-22.65)\end{array}$ & $\begin{array}{l}0.339^{* *} \\
(16.33)\end{array}$ & $\begin{array}{l}-0.423^{* *} \\
(-23.81)\end{array}$ & $\begin{array}{l}0.360^{* *} \\
(17.06)\end{array}$ & $\begin{array}{l}-0.423^{* *} \\
(-23.84)\end{array}$ & $\begin{array}{l}0.361^{* *} \\
(17.41)\end{array}$ \\
\hline Lagged exit $t_{i j t}$ & & $\begin{array}{l}0.264^{* *} \\
(12.75)\end{array}$ & $\begin{array}{l}-0.559 * * \\
(-27.63)\end{array}$ & $\begin{array}{l}0.264^{* *} \\
(12.74)\end{array}$ & $\begin{array}{l}-0.559^{* *} \\
(-27.65)\end{array}$ & $\begin{array}{l}0.278^{* *} \\
(13.19)\end{array}$ & $\begin{array}{l}-0.581^{* *} \\
(-28.97)\end{array}$ & $\begin{array}{l}0.279^{* *} \\
(13.26)\end{array}$ & $\begin{array}{l}-0.582^{* *} \\
(-29.04)\end{array}$ \\
\hline Change in entry & & & $\begin{array}{l}0.401^{* *} \\
(15.99)\end{array}$ & & $\begin{array}{l}0.400^{* *} \\
(15.95)\end{array}$ & & $\begin{array}{l}0.410^{* *} \\
(17.06)\end{array}$ & & $\begin{array}{l}0.412^{* *} \\
(17.16)\end{array}$ \\
\hline Change in exit $t_{j i t}$ & & $\begin{array}{l}0.319^{* *} \\
(15.99)\end{array}$ & & $\begin{array}{l}0.318^{* *} \\
(15.95)\end{array}$ & & $\begin{array}{l}0.339^{* *} \\
(17.06)\end{array}$ & & $\begin{array}{l}0.341^{* *} \\
(17.16)\end{array}$ & \\
\hline Country-time effects & & $\sqrt{ }$ & $\sqrt{ }$ & $\sqrt{ }$ & $\sqrt{ }$ & $\sqrt{ }$ & $\sqrt{ }$ & $\sqrt{ }$ & $\sqrt{ }$ \\
\hline Industry effects & & v & v & v & v & v & v & j & v \\
\hline Observations & & 1867 & 1867 & 1867 & 1867 & 1944 & 1944 & 1944 & 1944 \\
\hline$R$-squared & & 0.42 & 0.51 & 0.42 & 0.51 & 0.46 & 0.54 & 0.46 & 0.54 \\
\hline
\end{tabular}


Table 10: Instrumental variable estimates

\begin{tabular}{|c|c|c|}
\hline $\begin{array}{l}\text { Regression No. } \\
\text { Dependent variable }\end{array}$ & $\begin{array}{c}1 \\
\text { Entry Rate }\end{array}$ & $\begin{array}{c}2 \\
\text { Exit Rate }\end{array}$ \\
\hline \multicolumn{3}{|c|}{ Second-stage IV results } \\
\hline \multicolumn{3}{|l|}{ Profitability $_{j} x$} \\
\hline 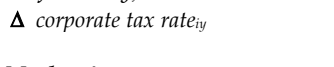 & $\begin{array}{l}-0.331^{* *} \\
(-2.59)\end{array}$ & $\begin{array}{l}-0.200 \\
(-1.42)\end{array}$ \\
\hline \multicolumn{3}{|l|}{ Market Access $_{i j t}$} \\
\hline Short run effect & $\begin{array}{l}0.640^{* *} \\
(2.97)\end{array}$ & $\begin{array}{l}-0.219 \\
(-0.71)\end{array}$ \\
\hline Long run effect & $\begin{array}{l}0.010 \\
(0.22)\end{array}$ & $\begin{array}{l}-0.026 \\
(-0.46)\end{array}$ \\
\hline Lagged Entry $y_{i j t}$ & $\begin{array}{c}-0.304^{* *} \\
(-5.97)\end{array}$ & $\begin{array}{c}0.276^{\star *} \\
(5.01)\end{array}$ \\
\hline Lagged Exit ${ }_{i j t}$ & $\begin{array}{l}0.136^{*} \\
(2.25)\end{array}$ & $\begin{array}{l}-0.708^{* *} \\
(-10.62)\end{array}$ \\
\hline \multicolumn{2}{|l|}{ Change in entry $y_{i j t}$} & $\begin{array}{c}0.325^{\star *} \\
(3.70)\end{array}$ \\
\hline Change in exitijt & $\begin{array}{l}0.162^{* *} \\
(4.12)\end{array}$ & \\
\hline \multicolumn{3}{|c|}{ First-stage IV results, dependent variable: profitability $\mathrm{x} \square$ corporate tax rateiy } \\
\hline Neighbour's tax rate ${ }_{i t-1}$ & $\begin{array}{c}-2.726^{* *} \\
(-4.65)\end{array}$ & $\begin{array}{c}-2.718^{* *} \\
(-4.52)\end{array}$ \\
\hline Government majority $_{i t}$ & $\begin{array}{l}-2.253^{* *} \\
(-7.79)\end{array}$ & $\begin{array}{l}-2.264 \\
(-7.72)\end{array}$ \\
\hline Government stability $_{i t}$ & $\begin{array}{l}0.111^{*} \\
(2.48)\end{array}$ & $\begin{array}{l}0.108^{*} \\
(2.40)\end{array}$ \\
\hline Veto tenure $_{i t}$ & $\begin{array}{l}0.020^{* *} \\
(5.57)\end{array}$ & $\begin{array}{l}0.020^{* *} \\
(5.50)\end{array}$ \\
\hline Legislative election $_{i t}$ & $\begin{array}{l}0.008 \\
(0.70)\end{array}$ & $\begin{array}{l}0.009 \\
(0.77)\end{array}$ \\
\hline Cragg-Donald F statistic & 17.210 & 17.103 \\
\hline Kleibergen-Paap F statistic & 15.815 & 15.300 \\
\hline Overidentification test ( $\mathrm{p}$-value) & 0.18 & 0.10 \\
\hline Observations & 1112 & 1112 \\
\hline
\end{tabular}


Table 11: Relationship between entrepreneurship, income taxation and industry profitability

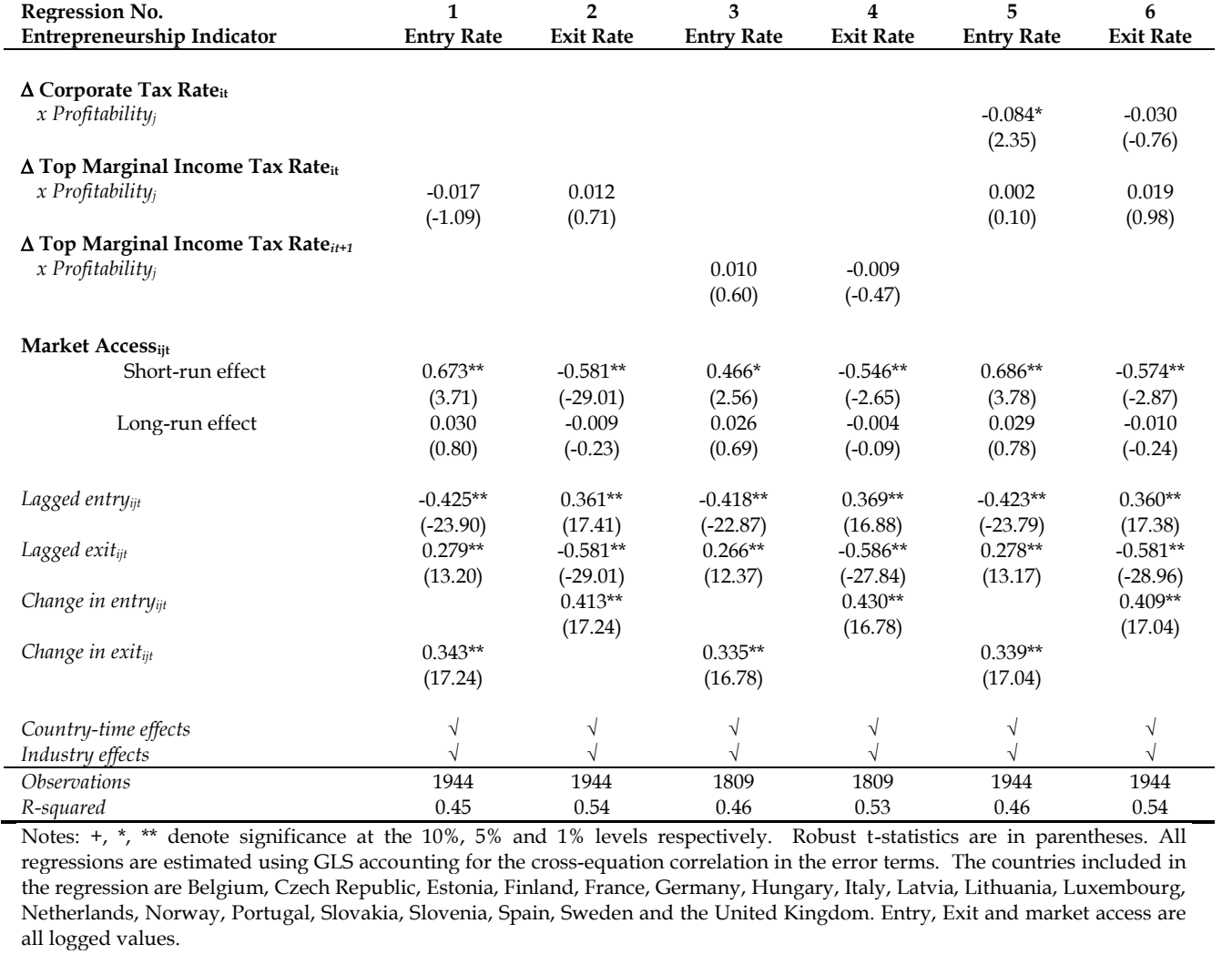


Table 12: Additional measure of Personal Income Taxation

\begin{tabular}{|c|c|c|c|c|c|c|c|c|}
\hline Regression No. & $\begin{array}{c}1 \\
\text { Entry Rate }\end{array}$ & $\begin{array}{c}2 \\
\text { Exit Rate }\end{array}$ & $\begin{array}{c}3 \\
\text { Entry Rate }\end{array}$ & $\begin{array}{c}4 \\
\text { Exit Rate }\end{array}$ & $\begin{array}{c}5 \\
\text { Entry Rate }\end{array}$ & $\begin{array}{c}6 \\
\text { Exit } \\
\text { Rate } \\
\end{array}$ & $\begin{array}{c}7 \\
\text { Entry Rate }\end{array}$ & $\begin{array}{c}8 \\
\text { Exit } \\
\text { Rate } \\
\end{array}$ \\
\hline \multicolumn{9}{|l|}{ Profitability $_{j} x$} \\
\hline$\Delta$ corporate tax rate $_{i y}$ & $\begin{array}{l}-0.095^{*} \\
(-2.22)\end{array}$ & $\begin{array}{l}-0.050 \\
(-1.07)\end{array}$ & $\begin{array}{l}-0.122^{* *} \\
(-2.90)\end{array}$ & $\begin{array}{l}-0.039 \\
(-0.85)\end{array}$ & $\begin{array}{l}-0.131^{* *} \\
(-3.09)\end{array}$ & $\begin{array}{l}-0.016 \\
(-0.36)\end{array}$ & $\begin{array}{l}-0.099^{*} \\
(-2.29)\end{array}$ & $\begin{array}{l}-0.028 \\
(-0.59)\end{array}$ \\
\hline $\begin{array}{l}\Delta \text { personal inc tax at } 67 \% \text { of } \\
\text { average wagesit }\end{array}$ & $\begin{array}{l}-0.099^{* *} \\
(-3.01)\end{array}$ & $\begin{array}{l}0.041 \\
(1.14)\end{array}$ & & & & & $\begin{array}{l}-0.117^{* *} \\
(-3.47)\end{array}$ & $\begin{array}{l}0.043 \\
(1.17)\end{array}$ \\
\hline $\begin{array}{l}\Delta \text { personal inc tax at } 100 \% \text { of } \\
\text { average wagesit }\end{array}$ & & & $\begin{array}{l}0.017^{*} \\
(2.23)\end{array}$ & $\begin{array}{l}-0.010 \\
(-1.15)\end{array}$ & & & $\begin{array}{l}0.023^{* *} \\
(2.96)\end{array}$ & $\begin{array}{l}-0.012 \\
(-1.39)\end{array}$ \\
\hline $\begin{array}{l}\Delta \text { personal inc tax at } 167 \% \text { of } \\
\text { average wages } 1 \text { it }\end{array}$ & & & & & $\begin{array}{l}0.019^{*} \\
(2.26)\end{array}$ & $\begin{array}{l}-0.044^{* *} \\
(-4.82)\end{array}$ & $\begin{array}{l}0.018^{*} \\
(2.05)\end{array}$ & $\begin{array}{l}-0.043^{* *} \\
(-4.74)\end{array}$ \\
\hline \multicolumn{9}{|l|}{ Market Access $i j t$} \\
\hline Short run effect & $\begin{array}{l}0.487^{*} \\
(2.44)\end{array}$ & $\begin{array}{l}-0.491^{*} \\
(-2.25)\end{array}$ & $\begin{array}{l}0.500^{*} \\
(2.50)\end{array}$ & $\begin{array}{l}-0.496^{*} \\
(-2.28)\end{array}$ & $\begin{array}{l}0.479^{*} \\
(2.39)\end{array}$ & $\begin{array}{l}-0.445^{*} \\
(-2.06)\end{array}$ & $\begin{array}{l}0.469^{*} \\
(2.36)\end{array}$ & $\begin{array}{l}-0.443^{*} \\
(-2.05)\end{array}$ \\
\hline Long run effect & $\begin{array}{l}-0.003 \\
(-0.07)\end{array}$ & $\begin{array}{l}0.028 \\
(0.58)\end{array}$ & $\begin{array}{l}-0.000 \\
(-0.00)\end{array}$ & $\begin{array}{l}0.026 \\
(0.55)\end{array}$ & $\begin{array}{l}-0.005 \\
(-0.11)\end{array}$ & $\begin{array}{l}0.034 \\
(0.73)\end{array}$ & $\begin{array}{l}-0.005 \\
(-0.11)\end{array}$ & $\begin{array}{l}0.034 \\
(0.73)\end{array}$ \\
\hline Lagged Entry & $\begin{array}{l}-0.446^{* *} \\
(-19.34)\end{array}$ & $\begin{array}{l}0.463^{* *} \\
(18.11)\end{array}$ & $\begin{array}{l}-0.444^{* *} \\
(-19.18)\end{array}$ & $\begin{array}{l}0.461^{* *} \\
(18.04)\end{array}$ & $\begin{array}{l}-0.446^{* *} \\
(-19.30)\end{array}$ & $\begin{array}{l}0.457^{* *} \\
(18.06)\end{array}$ & $\begin{array}{l}-0.443^{* *} \\
(-19.27)\end{array}$ & $\begin{array}{l}0.458^{* *} \\
(18.06)\end{array}$ \\
\hline Lagged Exit $t_{j t}$ & $\begin{array}{l}0.323^{* *} \\
(12.80)\end{array}$ & $\begin{array}{l}-0.619^{* *} \\
(-27.15)\end{array}$ & $\begin{array}{l}0.322^{* *} \\
(12.71)\end{array}$ & $\begin{array}{l}-0.618^{* *} \\
(-27.09)\end{array}$ & $\begin{array}{l}0.325^{* *} \\
(12.82)\end{array}$ & $\begin{array}{l}-0.612^{* *} \\
(-27.06)\end{array}$ & $\begin{array}{l}0.323^{* *} \\
(12.83)\end{array}$ & $\begin{array}{l}-0.612^{* *} \\
(-27.05)\end{array}$ \\
\hline Change in entry $y_{j i t}$ & & $\begin{array}{l}0.433^{* * *} \\
(14.41)\end{array}$ & & $\begin{array}{l}0.437^{* *} \\
(14.40)\end{array}$ & & $\begin{array}{l}0.437^{* *} \\
(14.56)\end{array}$ & & $\begin{array}{l}0.443^{* *} \\
(14.66)\end{array}$ \\
\hline Change in exit $t_{j t}$ & $\begin{array}{l}0.369^{* *} \\
(14.41)\end{array}$ & & $\begin{array}{l}0.369^{* *} \\
(14.40)\end{array}$ & & $\begin{array}{l}0.377^{* *} \\
(14.56)\end{array}$ & & $\begin{array}{l}0.376^{* *} \\
(14.66)\end{array}$ & \\
\hline Observations & 1176 & 1176 & 1176 & 1176 & 1176 & 1176 & 1176 & 1176 \\
\hline$R$-squared & 0.33 & 0.47 & 0.33 & 0.47 & 0.33 & 0.48 & 0.33 & 0.48 \\
\hline
\end{tabular}


Figure 1: Rate of Entry and Exit in UK Textiles Sector, 1998-2005

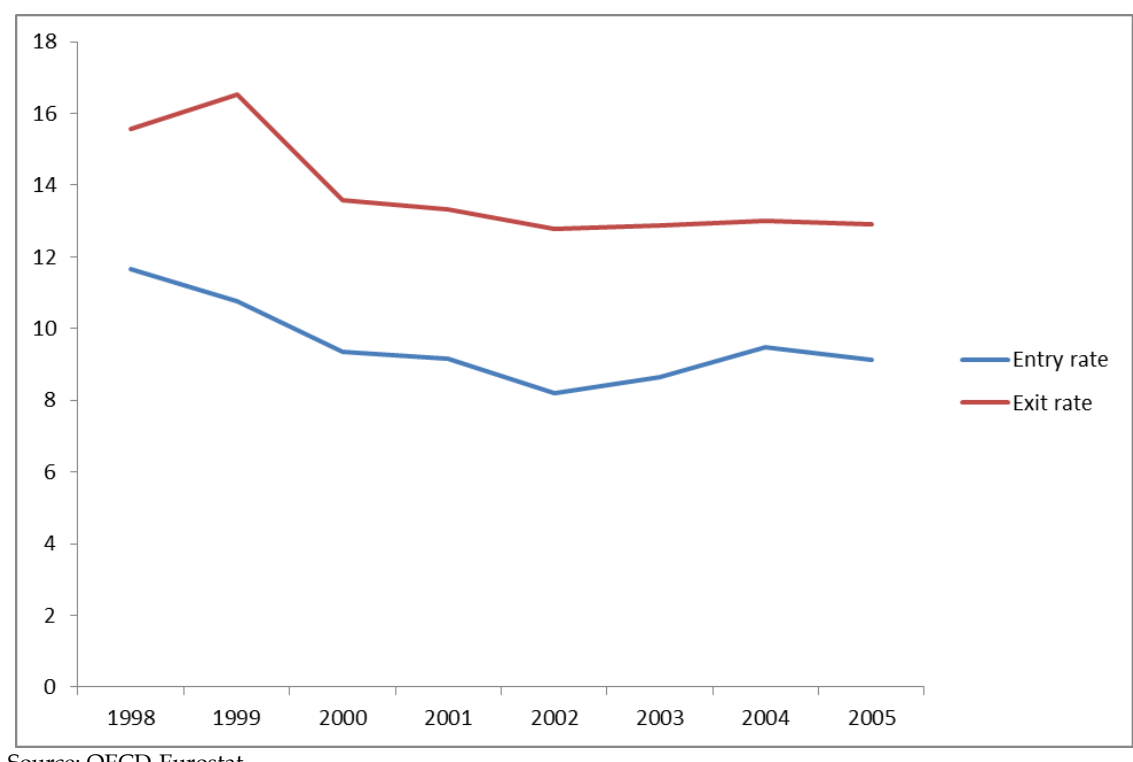

Figure 2: Rate of Entry and Exit in UK Hotels and Restaurant Sector, 1998-2005

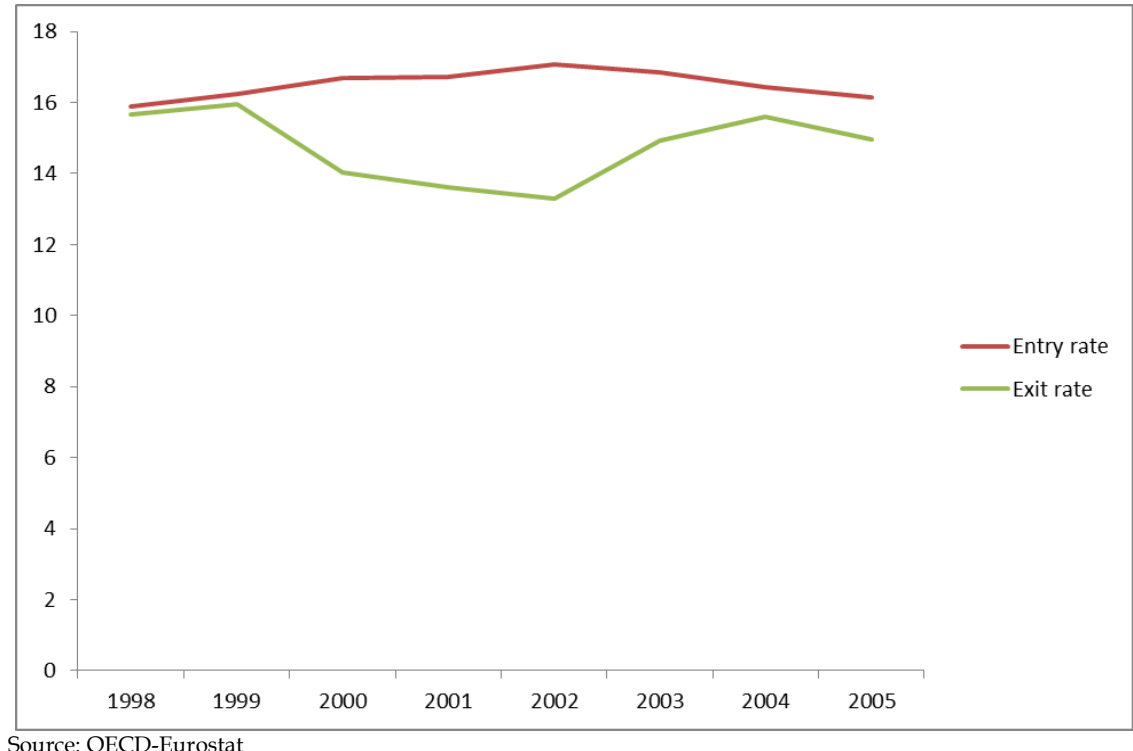


Figure 3: Impact of a Decrease in Corporation Taxes Across Industries

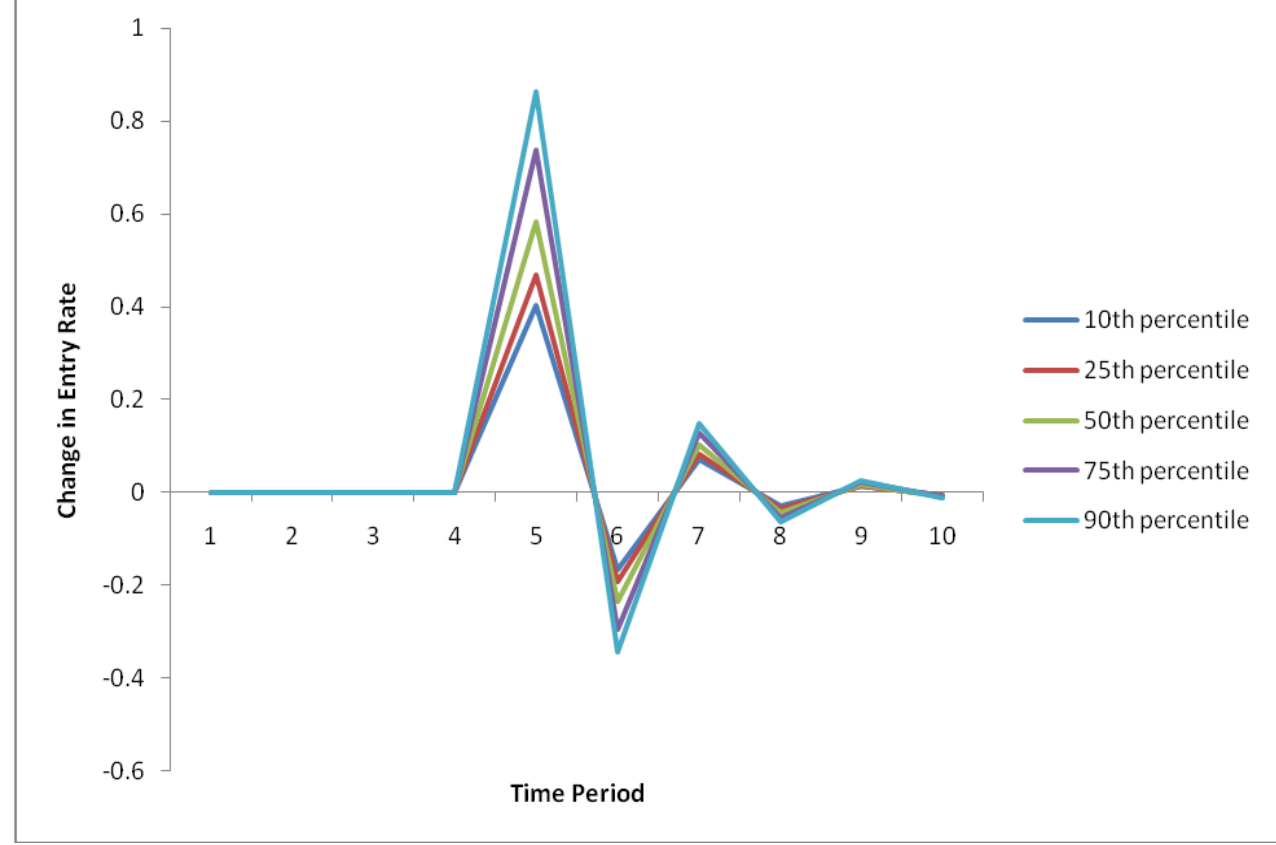

Notes: These figures use the parameter estimates from regression 1 in Table 7 . The change in entry rates are calculated as the percentage point change. All numbers are calculated using the average rate of entry across all data points of 8.9 per cent. Profitability figures for the $10^{\text {th }}, 25^{\text {th }}, 50^{\text {th }}, 75^{\text {th }}$ and $90^{\text {th }}$ perecentiles are $22.3,25.7,31.9,39.9,46.5$.

Figure 4: Impact of a Decrease in Personal Tax Rates at 67\% of Average Wages Across Industries

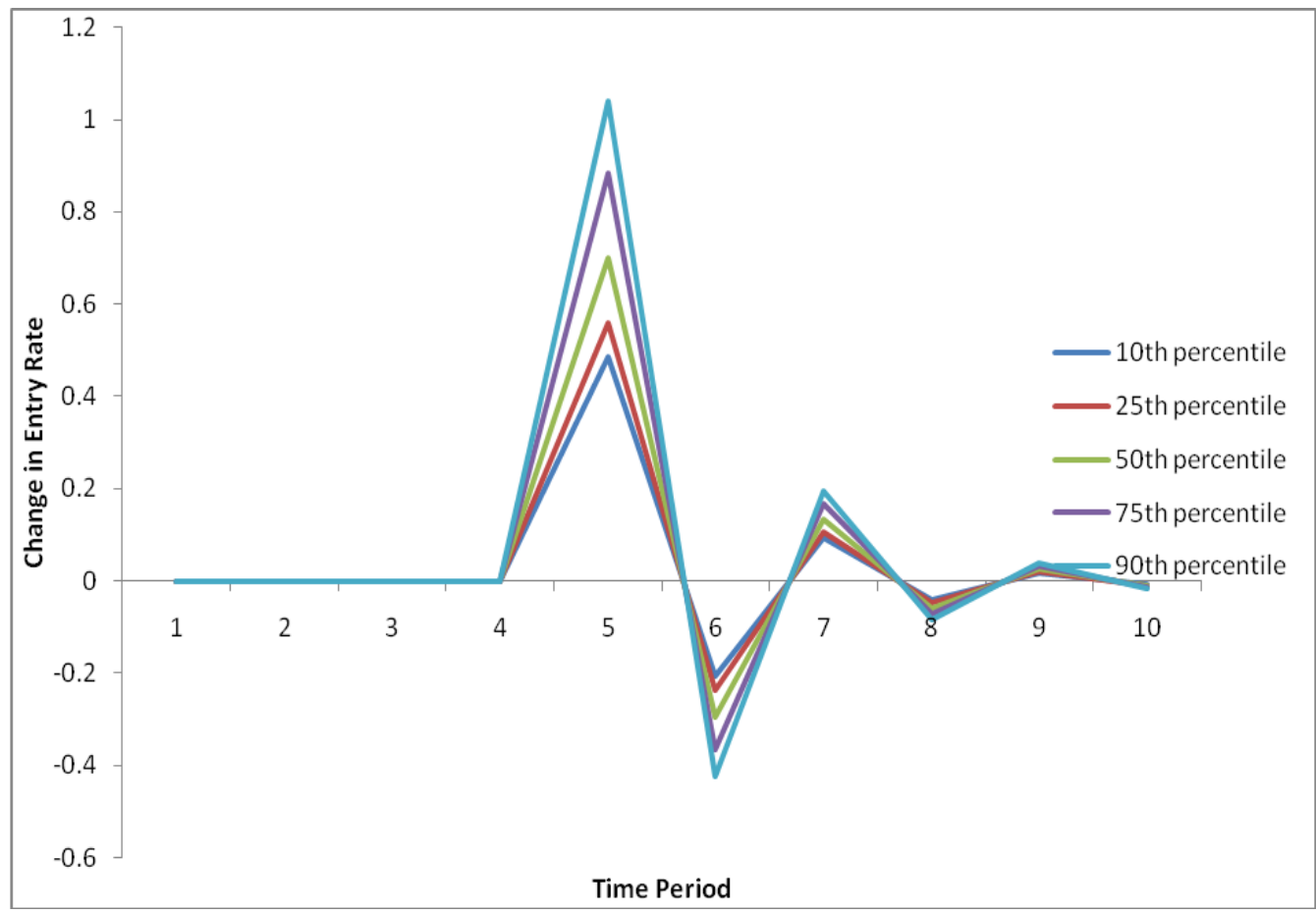

Notes: These figures use the parameter estimates from regression 1 in Table 10. The change in entry rates are calculated as the percentage point change. All numbers are calculated using the average rate of entry across all data points of 8.9 per cent. Profitability figures for the $10^{\text {th }}, 25^{\text {th }}, 50^{\text {th }}, 75^{\text {th }}$ and $90^{\text {th }}$ perecentiles are $22.3,25.7,31.9,39.9,46.5$. 